\title{
Petrogenesis of the late-orogenic Bravo granite and surrounding high-grade country rocks in the Palaeoproterozoic orogen of Itabuna-Salvador-Curaçá block, Bahia, Brazil
}

\author{
Johildo Figueiredo Salomão Barbosa ${ }^{\mathrm{a}, *}$, Jean-Jacques Peucat ${ }^{\mathrm{b}}$, Hervé Martin ${ }^{\mathrm{c}}$, \\ Fernando Alves da Silva ${ }^{\mathrm{d}}$, Antonio Marcos de Moraes ${ }^{\mathrm{e}}$, Luiz César Corrêa-Gomes ${ }^{\mathrm{a}, \mathrm{f}}$, \\ Pierre Sabaté $^{g, 1}$, Moacyr M. Marinho ${ }^{\mathrm{e}}$, C. Mark Fanning ${ }^{\mathrm{h}}$ \\ a CPGG-Centro de Pesquisa em Geofísica e Geologia, UFBA, Universidade Federal da Bahia, Rua Caetano Moura 123, Federação, \\ CEP 40210-340 Salvador, Bahia, Brazil \\ b Géosciences Rennes, UMR-CNRS 6118, Université de Rennes 1, 35042 Rennes, France \\ ${ }^{\mathrm{c}}$ Laboratoire Magmas et Volcans, OPGC, CNRS, Université Blaise Pascal, 5 rue Kessler, 63038 Clermont-Ferrand, France \\ d Universidade Federal do Rio Grande do Norte, Instituto de Geociências e PPGG-Curso de Pós-Graduação em Geodinâmica e Geofísica, Caixa Postal 1639 Natal, RN, Brazil \\ e CBPM-Companhia Baiana de Pesquisa Mineral, Quarta Avenida, $N^{\circ}$ 460, Centro Administrativo, CEP 41750-300 Salvador, Bahia, Brazil \\ ${ }^{\mathrm{f}}$ Departamento de Ciências Aplicadas, Centro Federal de Educação Tecnológica da Bahia, Rua Emidio Santos s/n, Barbalho, CEP 40030-010 Salvador, Bahia, Brazil \\ I IRD-Representation in Brazil-CP7091, Lago Sul, 71619-970 Brasilia, DF, Brazil \\ ${ }^{\text {h }}$ Research School of Earth Sciences, ANU, Canberra, ACT 0200, Australia
}

\section{A R T I C L E I N F O}

\section{Article history:}

Received 7 December 2007

Received in revised form 31 May 2008

Accepted 6 June 2008

\section{Keywords:}

São Francisco Craton

Itabuna-Salvador-Curaçá orogen

Palaeoproterozoic

Granulite

Brazil

\begin{abstract}
A B S T R A C T
In the São Francisco Craton, in Bahia state, Brazil, four Archaean crustal segments collided during the Palaeoproterozoic to form the important Itabuna-Salvador-Curaçá Orogen (ISCO). Granulites were formed in the central, deepest part of the ISCO while rocks in amphibolite to greenschist facies were formed at the borders. During the uplift of the orogen shear zones, faults and fractures provided channels for the intrusion of granites and syenites into the granulitic country rocks which reached higher crustal levels. This article reports a study of the Bravo granite with a zircon U-Pb SHRIMP age of $2060 \pm 6 \mathrm{Ma}$, and of its granulite host rocks formed from Archaean and Palaeoproterozoic protoliths in the Bravo and Tanquinho regions. The metamorphic peak occurred between $2064 \pm 6 \mathrm{Ma}$ and $2060 \pm 6 \mathrm{Ma}$ in the Bravo region. The Bravo granite is mostly metaluminous and alkaline due to high $\mathrm{K}_{2} \mathrm{O}$ contents (4.03-5.95\%) which confer high-K to shoshonitic affinities. It is slightly younger than syenites of the orogen (Itiúba, $2084 \pm 9 \mathrm{Ma}$; São Felix, $2098 \pm 1 \mathrm{Ma}$ ) which are cut by late felsic veins chemically similar to the Bravo granite. The granulitic rocks form a peraluminous, medium-K calc-alkaline TTG suite. It is proposed that residual liquids represented by the vein rocks and the Bravo granite escaped from the syenitic cumulates, and migrated upwards through crustal discontinuities formed during the uplift of the ISCO.
\end{abstract}

(C) 2008 Elsevier B.V. All rights reserved.

\section{Introduction}

The granitoids of the Itabuna-Salvador-Curaçá Orogen (ISCO) can be separated into syn-tectonic (synchronous of the fold belts) and post-tectonic (associated with late uplift and major strike-slip faulting) magmas. Among post-tectonic granites, the A-type ones

\footnotetext{
* Corresponding author. Tel.: +55 2171 32838606; fax: +55 217132838501.

E-mail addresses: johildo@cpgg.ufba.br (J.F.S. Barbosa), peucat@univ-rennes1.fr (J.-J. Peucat), H.Martin@opgc.univ-bpclermont.fr (H. Martin), fernando@geologia.ufrn.br (F.A. da Silva),gomes@cefetba.br, lccgomes@ufba.br (L.C. Corrêa-Gomes), ird@apis.com.br (P. Sabaté), prise.fanning@anu.edu.au (C.M. Fanning).

1 Tel.: +55 21612485378 .
}

have recently received much attention due to both their economic potential value and their tectonic significance.

Many pre-, syn-, late- and post-tectonic granite and syenite intrusions occurred in the Itabuna-Salvador-Curaçá Orogen that is part of the São Francisco Craton, in Bahia state in Brazil (Barbosa and Sabaté, 2002, 2004; Barbosa et al., 2005). In the ISCO, granulites were uplifted to shallow crustal levels where they were affected by shear zones and faults into which late-tectonic syenites and posttectonic granites intruded. All these rocks have similar ages $(\sim 2.07$ $\mathrm{Ga}$ ) which are akin that of the peak of the regional granulite facies metamorphism.

In the Bravo and Tanquinho regions (Figs. 1 and 2), a detailed study was performed, including: detailed mapping of intrusive granites and surrounding granulites petrology, whole-rock 


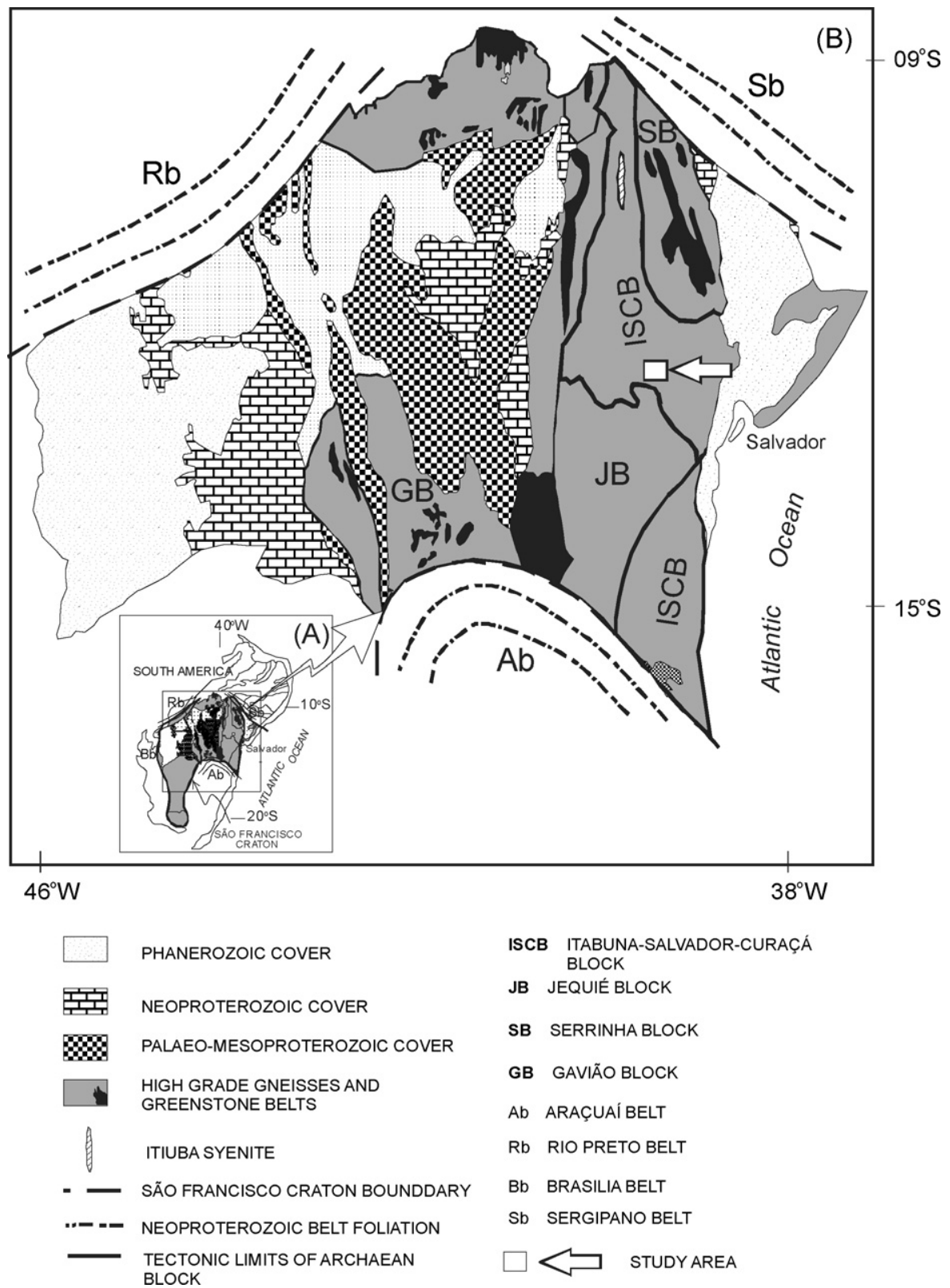

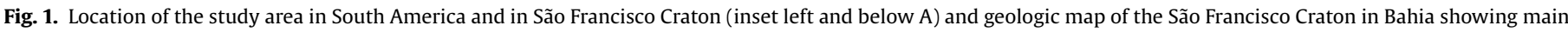
Archaean and Palaeoproterozoic units and surrounding Neoproterozoic fold belts (B). Modified from Barbosa and Sabaté (2004).

major- and trace-elements, as well as isotope geochemistry and geochronology.

The results presented here allow a discussion of the tectonic context of these rocks, and contribute to a better understanding of the ISCO, and thus of the Archaean-Proterozoic transition.

\section{The São Francisco Craton}

\subsection{Major geologic units}

Together with the Amazonian craton, the São Francisco craton (Almeida, 1977) is one of the most important crustal units in South America. Its cratonisation took place prior to Brasiliano (Pan African) orogeny (Caby et al., 1981; Jardim de Sá et al., 1984). It is limited by heterogeneous fold belts, mainly of metasedimentary origin, metamorphosed in greenschist to amphibolite facies, and intruded by granitoids. These fold belts whose ages range between
700 and 400 Ma are: the Sergipano (North-East), the Rio Preto (North), the Brasilia (West) and the Ribeira and Araçuai (South) belts (Fig. 1).

The main part of the São Francisco craton consists of (i) a Meso to Neoproterozoic sedimentary cover, which remained almost undeformed during the Brasiliano orogeny and (ii) an Archaean and Palaeoproterozoic crystalline basement. The latter can be subdivided into four major geological units (Fig. 1): the Gavião, the Serrinha, the Jequié and the Itabuna-Salvador-Curaçá blocks which are supposed to have been amalgamated during a complex and not synchronous collision at ca. 2.0 Ga (Barbosa and Sabaté, 2002, 2004).

The Gavião block (GB) is mainly made of tonalitic to granodioritic orthogneisses including TTG suites and gneiss-amphibolite associations whose ages range from 2.8 to $2.9 \mathrm{Ga}$, and greenstone belts with ages ranging from 3.5 to $2.7 \mathrm{Ga}$ (Brito Neves et al., 1980; Cordani et al., 1985; Marinho, 1991; Martin et al., 1991; Nutman and 


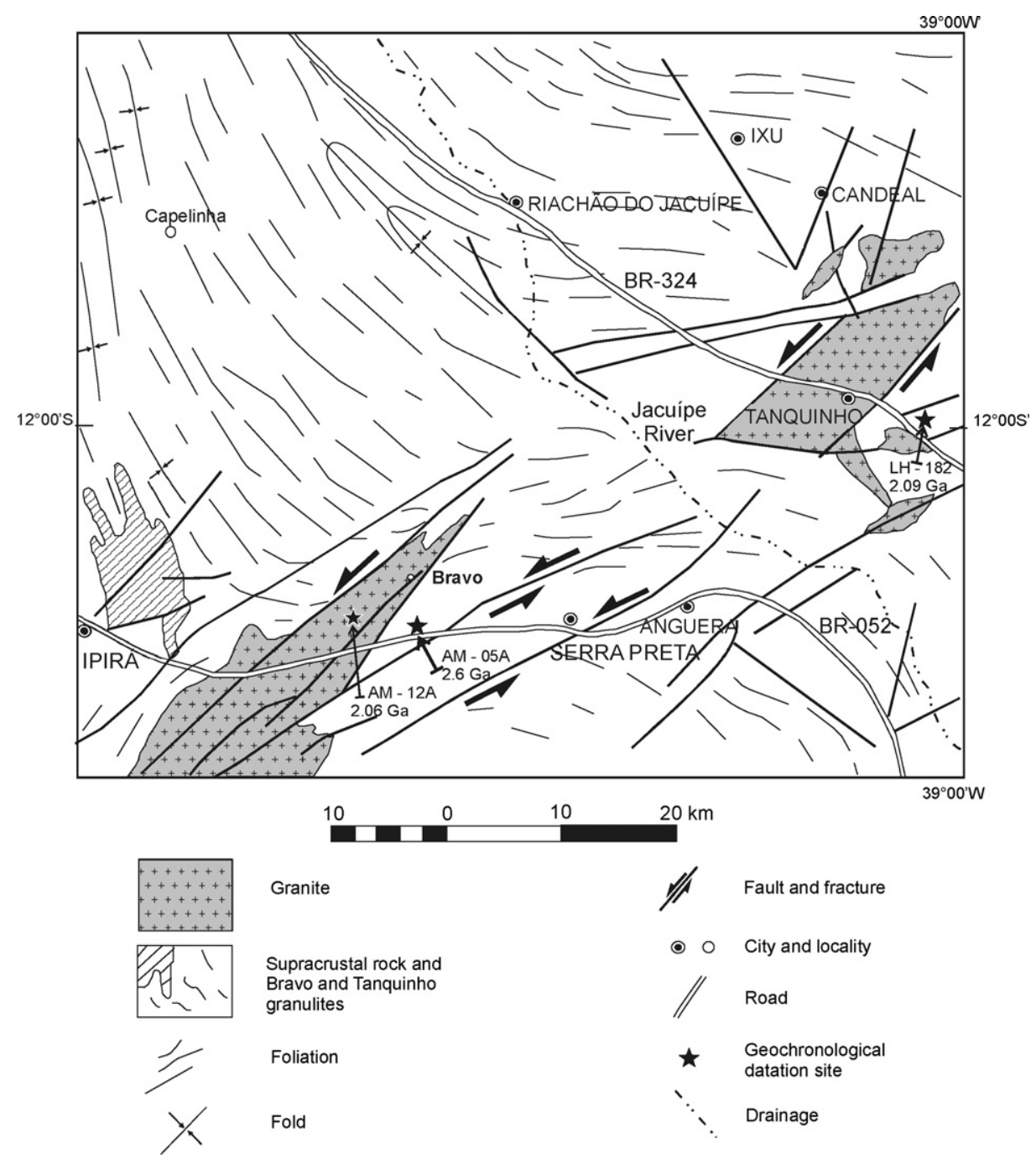

Fig. 2. Geologic map of Bravo and Tanquinho regions. Simplified from Barbosa and Dominguez (1996).

Cordani, 1993; Santos Pinto, 1996; Santos Pinto et al., 1998; Cunha et al., 1996; Peucat et al., 2002). Inside these formations 3.4-3.1 Ga TTG massifs (Sete Voltas, Boa Vista, Mata Verde, Bernarda, Aracatu) are amongst the oldest crustal components so far recorded in South America. In addition, old inherited zircon cores in the Sete Voltas and Aracatu gneisses, as well as systematic old (3.5-3.6 Ga) Nd model ages reported in the whole Gavião block (Martin et al., 1997; Santos Pinto et al., 1998; Peucat et al., 2003) favour the assumption that an even older crust (up to $3.6 \mathrm{Ga}$ ) existed in this block. The Archaean Contendas Mirante, Umburanas, Riacho de Santana, Mundo Novo low metamorphic grade greenstone belts are located in the Gavião block. They typically contain spinifex textured komatiites overlain by mafic and felsic, lavas together with pyroclastic rocks themselves covered by siliciclastic sediments (Marinho, 1991; Cunha et al., 1996; Mascarenhas and Alves de Silva, 1994; Peucat et al., 2002).

The Serrinha block (SB) is made up of banded gneisses, amphibolitic and granodioritic orthogneisses metamorphosed in amphibolite facies and dated at ca. 3.1 to $2.8 \mathrm{Ga}$ (Padilha and Melo, 1991; Rios, 2002; Mello et al., 2006). The Rio Itapirucu and Rio Capim greenstone belts are Palaeoproterozoic in age (Silva, 1996; Winge, 1984).

The granulitic Jequié block (JB) (Barbosa, 1986, 1990) contains important domains made of granodiorite to granite whose magmatic ages range between 2.7-2.8 Ga. They crosscut 2.9 Ga heterogeneous migmatites (Wilson, 1987; Barbosa et al., 2004) which are associated with supracrustal rocks including metabasalts, andesitic metabasalts, quartzites, banded iron formation, graphite layers and partially migmatized aluminous gneisses. The latter occasionally contain garnet- and cordierite-bearing anatectic granites. The whole Jequié block has been affected by a major Palaeoproterozoic (2.1-2.05 Ga) granulitic event (Barbosa and Sabaté, 2002, 2004), associated with the intrusion of synmetamorphic plutons (Barbosa et al., 2004).

The Itabuna-Salvador-Curaçá block (ISCB) extends N-S over $700 \mathrm{~km}$; it is also affected by a granulite facies metamorphism (Padilha and Melo, 1991; Barbosa, 1986, 1990; Silva et al., 2002; Oliveira et al., 2004, Fig. 1). Three major stages of ductile deformation, contemporaneous with high-grade metamorphism, are observed in the whole ISCB, and have been dated at ca. 2.0-2.1 Ga (Wilson, 1987; Ledru et al., 1994; Silva et al., 1997; Oliveira et al., $2002,2004)$. The first stage is characterized by a flat horizontal foliation, with regional folds with horizontal axial planes. The second stage is approximately coaxial with the first one. In the JB and ISCB the main axial planes are subvertical, but the folds in the JB are more open. The third stage has a vertical foliation with a sub-horizontal lineation with transposed zones parallel to axial planes of folds of the second stage. These observations together with the geometry 
of sigmoid porphyroblasts indicate movement from SW toward NE (Fig. 2). Barbosa and Fonteilles (1991) calculated minimum pressures of $5-7 \mathrm{kbar}$ and temperatures of $850-870^{\circ} \mathrm{C}$ for the granulitic metamorphism. Retro-metamorphic mineral assemblages associated with tectonic transposition zones have been interpreted as products of re-equilibration during uplift of the granulites (Barbosa, 1986, 1990).

\subsection{Southern part of the Itabuna-Salvador-Curacá block}

This domain has been subjected to several studies which where mainly focused on determining the origin of the protolith, the ages and P-T conditions of the granulitic metamorphism. Main references are Barbosa (1986, 1990), Wilson (1987), Barbosa and Fonteilles (1991), Aillon (1992), Alibert and Barbosa (1992) and Ledru et al. (1994). In field all that rocks look as homogeneous green-brown granulites but their geochemical signatures show different affinities: (1) low-K calc-alkaline tonalitic gneisses containing supracrustal enclaves; (2) mafic granulites whose tholeiitic composition is very similar to oceanic basalts (Barbosa, 1986, 1990); (3) monzonitic gneissic granulites with shoshonitic affinities (Barbosa, 1990).

\subsection{Northern part of the Itabuna-Salvador-Curaçá block}

This domain is composed of three strongly deformed main granulitic complexes: (1) Caraíba, (2) Ipirá and (3) São José do Jacuípe (Teixeira, 1997; Melo et al., 1991). The Caraíba complex contains an association of calc-alkaline orthogneisses with compositions ranging from tonalitic to granitic, with subordinate amounts of dioritic and granodioritic gneisses. Melo et al. (1995) considered the Caraíba unit as a bimodal suite, where the felsic member is tonalitic-trondhjemitic-granodioritic and the basic member gabbroic to dioritic. In the Caraíba Complex, magmatic zircon give Archaean ages ca. 2.8-2.6 Ga (Silva et al., 2002; Oliveira et al., 2004). The Caraíba complex is cut, on its northern part, by the Itiúba syenite dated at $2084 \pm 9 \mathrm{Ma}$ (Oliveira et al., 2004) by SHRIMP on zircon crystals. The Ipirá complex consists in supracrustals, such as calcsilicate rocks, marble, quartzites, graphitic gneisses, kinzigites and banded iron formations. Metabasites and meta-ultrabasites can be found associated to these supracrustals. The São José do Jacuípe granulitic complex is considered by Teixeira (1997) to be mainly composed of gabbro-norites, peridotites and pyroxenites. These rocks of tholeiitic affinities are thought to represent ancient oceanic crust. The Bravo-Tanquinho region is situated in this part of the ISCB.

\section{Local geology and petrography}

\subsection{Bravo and Tanquinho granulites}

Enderbitic, charnoenderbitic and charnockitic granulites are the dominant rock types in the Bravo and Tanquinho region. They always display NW-SE banding and foliation (Fig. 2). In the Q-A-P diagram of Streckeisen (1975) these granulites plot in the fields of tonalite and granodiorite with a few samples plotting in the granite field (Fig. 3).

Plutonic textures are sometimes preserved in the form of centimetre-wide magmatic bands in which the grain sizes vary from fine- to coarse-grained. Where the texture is porphyritic, quartz and plagioclase phenocrysts stand out in a fine-grained matrix consisting of the same minerals together with hypersthene, hornblende and biotite. The average modal composition of the more enderbitic members is $21-36 \%$ quartz, $40-68 \%$ of plagioclase, $4-15 \%$ hypersthene, $2-18 \%$ of clinopyroxene and $1-3 \%$ of mesoperthite. Charnoenderbitic-charnockitic members contain from 20 to $37 \%$

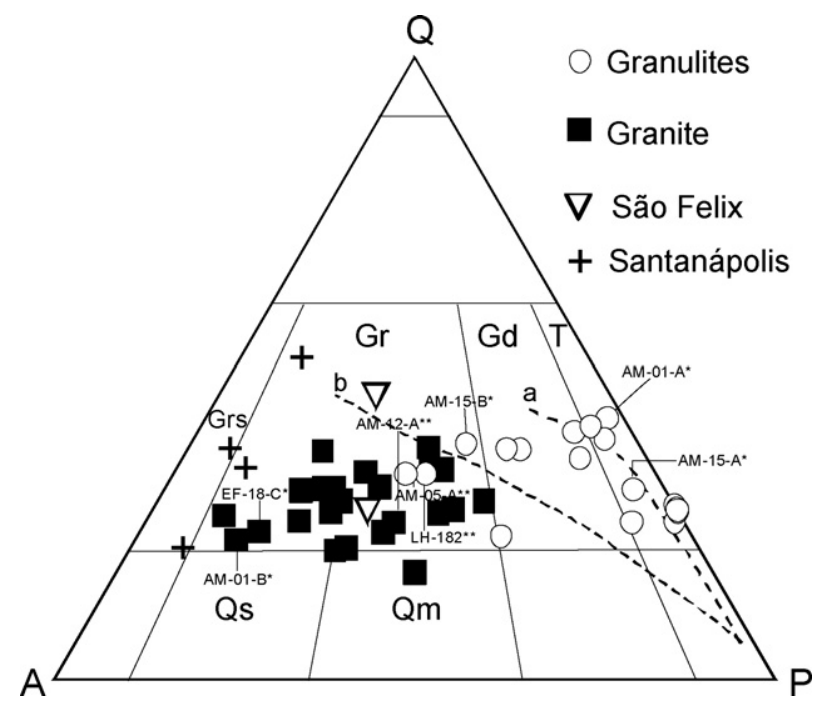

Fig. 3. Streckeisen (1975) diagram for the Bravo and Tanquinho granulitic country rocks and Bravo Granite. T, tonalite/enderbite; Gd, granodiorite/charnoenderbite; $\mathrm{Gr}$, granite/charnockite; Grs, syeno granite; Qs, quartz syenite; Qm, quartz monzonite. Dashed lines from Lameyre and Bowden (1982): a =calcalkaline low K; $\mathrm{b}=$ calcalkaline intermediate K. $\left({ }^{*}\right)$ Analysed for Sm/Nd; $\left({ }^{* *}\right)$ analysed for Sm/Nd and $\mathrm{Zr}$ age. Crosses and inverted triangle represent samples of dykes cutting the São Felix and Santanópolis syenites.

quartz, 7 to $49 \%$ mesoperthite, 12 to $53 \%$ plagioclase, 0 to $8 \%$ hypersthene, 0 to $6 \%$ of microcline and, in general, traces of clinopyroxene. Biotite is usually retrograded in both rock types, forming symplectites with quartz and sometimes forms up to $27 \%$ of the rock composition. Zircon and magnetite are common accessory phases (Table 1). Garnet is strictly restricted to the immediate vicinity of enclaves of supracrustal rocks.

These metaplutonic rocks rarely contain enclaves of metabasalts, calc-silicate rocks, quartzites and kinzigites.

\subsection{The Bravo granite}

Near Bravo village the NW-SE granulitic fabric of the ItabunaSalvador-Curaçá block is crosscut by a major sinistral NE-SW shear zone along which the Bravo pluton was emplaced under amphibolite facies conditions (Moraes, 1997). The pluton displays sharp contacts with the granulites (Fig. 2). The main foliation in the granite trends $\mathrm{N} 50^{\circ}-70^{\circ} \mathrm{E}$, while the dip is mainly upright but locally can be as shallow as $50^{\circ}$. The stretching mineral lineation is subhorizontal. Mylonitic textures are frequent along the pluton margins. Macro-scale shear criteria such as the drag of the foliation indicate sinistral movement. In the field in the vicinity of the pluton, meso-scale shear zones in the host granulites are filled with granitic material; they also point to sinistral sense of shear (Fig. 2). The Bravo pluton contains amphibolite facies mineral assemblages, which contrast with the granulitic assemblages of the host rocks. No contact metamorphism has been identified in the host rocks, however, the shear zone crosscuts the fabric of the ISCB granulites, thus evidencing the posteriority of the granite with respect to granulites.

The Bravo granite consists in an assemblage of microcline, orthoclase, quartz, plagioclase, hornblende and biotite together with subordinate amounts of magnetite and zircon. However, as shown in Table 1, the relative proportions of microcline, and orthoclase change from coarse-grained rocks (microcline $\gg$ orthoclase) to fine-grained ones (orthoclase $>$ microcline) through mediumgrained where microcline $\approx$ orthoclase. In the Streckeisen (1975) triangle, all modal compositions fall in the granite domain with 
Table 1

Petrographic data for the Tanquinho and Bravo granulitic country rocks and Bravo Granite

\begin{tabular}{|c|c|c|c|c|c|c|c|c|c|c|c|c|}
\hline \multirow[t]{2}{*}{ Rocks } & \multicolumn{10}{|c|}{ Major metamorphic minerals (modal composition) } & \multirow[t]{2}{*}{ Accessory minerals } & \multirow{2}{*}{$\begin{array}{l}\text { Retrograde metamorphic } \\
\text { minerals }\end{array}$} \\
\hline & Qtz & $\mathrm{Pl}$ & Mi & Opx & Cpx & $\mathrm{Bi}$ & $\mathrm{Hb}$ & Mp & Or & $\mathrm{Gt}$ & & \\
\hline \multicolumn{13}{|l|}{ Granulites } \\
\hline AM-09A & 31 & 44 & 3 & 5 & & & & & & & Op, Zr & Mo, Ep \\
\hline AM-14A & 20 & 44 & $\operatorname{tr}$ & 8 & 2 & & & 23 & & & & $\mathrm{Bi}$ \\
\hline $\mathrm{AM}-15 \mathrm{~B}^{\mathrm{a}}$ & 37 & 12 & $\operatorname{tr}$ & $\operatorname{tr}$ & & & & 49 & & & & \\
\hline $\mathrm{AM}-05 \mathrm{~A}^{\mathrm{b}}$ & 21 & 36 & $\operatorname{tr}$ & $\operatorname{tr}$ & & 19 & & 20 & & & Op & $\mathrm{Bi}$ \\
\hline AM-2A & 21 & 32 & 6 & $\operatorname{tr}$ & & 9 & & 25 & & 7 & $\mathrm{Op}, \mathrm{Zr}, \mathrm{Ap}$ & \\
\hline AM-04A & 34 & 53 & 2 & 3 & & $\mathrm{tr}$ & & 7 & & & $\mathrm{Op}, \mathrm{Zr}$ & Mo \\
\hline AM-15 C & 24 & 32 & 3 & 8 & 12 & 18 & & & & & $\mathrm{Op}, \mathrm{Zr}$ & \\
\hline LH-182 & 25 & 33 & 5 & 2 & & 10 & 15 & 7 & & & Op & \\
\hline \multicolumn{13}{|l|}{ Granulites } \\
\hline EF-12A & 36 & 48 & 1 & 4 & & 9 & & 1 & & & $\mathrm{Op}, \mathrm{Zr}$ & $\mathrm{Cl}$ \\
\hline EF-12B & 27 & 40 & 1 & 15 & & 14 & & 2 & & & $\mathrm{Op}, \mathrm{Zr}$ & \\
\hline AM-20A & 35 & 46 & 3 & 9 & & 3 & & 3 & & & $\mathrm{Op}, \mathrm{Zr}$ & $\operatorname{Tr}$ \\
\hline AM-31A & 21 & 61 & $\operatorname{tr}$ & 8 & 4 & 1 & & 1 & & 3 & $\mathrm{Op}, \mathrm{Zr}$ & \\
\hline $\mathrm{AM}-01 \mathrm{~A}^{\mathrm{a}}$ & 21 & 54 & & 13 & 8 & 3 & & $\operatorname{tr}$ & & & $\mathrm{Op}, \mathrm{Zr}, \mathrm{Ap}$ & $\operatorname{Tr}$ \\
\hline $\mathrm{AM}-15 \mathrm{~A}^{\mathrm{a}}$ & 21 & 46 & & 7 & 18 & 3 & & $\operatorname{tr}$ & & & $\mathrm{Op}, \mathrm{Zr}, \mathrm{Ap}$ & \\
\hline AM-11C3 & 25 & 68 & & 4 & 2 & $\operatorname{tr}$ & & $\operatorname{tr}$ & & & $\mathrm{Op}, \mathrm{Zr}$ & \\
\hline $\mathrm{AM}-15 \mathrm{~F}$ & 25 & 67 & & 4 & 3 & $\operatorname{tr}$ & & $\operatorname{tr}$ & & & & \\
\hline AM-19A & 21 & 35 & 3 & 3 & 3 & 27 & & 7 & & & $\mathrm{Op}, \mathrm{Zr}$ & $\mathrm{Cl}$ \\
\hline AM-24A & 21 & 56 & 3 & 6 & & 5 & & 7 & & & $\mathrm{Op}, \mathrm{Zr}$ & $\mathrm{Cl}$ \\
\hline \multicolumn{13}{|l|}{ Bravo granite } \\
\hline$A M-33 A$ & 26 & 33 & 12 & & & 7 & 9 & & 12 & & $\mathrm{Op}, \mathrm{Zr}$ & \\
\hline $\mathrm{AM}-01 \mathrm{~B}^{\mathrm{a}}$ & 27 & 17 & 17 & & & 5 & 5 & & 27 & & Op & \\
\hline AM-27A & 14 & 20 & 20 & & & 25 & 15 & & 5 & & Op & \\
\hline $\mathrm{AM}-26 \mathrm{~A}$ & 22 & 30 & 20 & & & 9 & 9 & & 9 & & Op & \\
\hline $\mathrm{AM}-12 \mathrm{~A}^{\mathrm{b}}$ & 28 & 25 & 11 & & & 15 & 9 & & 11 & & Op & \\
\hline AM-14B & 20 & 14 & 25 & & & 8 & 8 & & 24 & & $\mathrm{Op}, \mathrm{Zr}$ & \\
\hline AM-25A & 20 & 35 & 19 & & & 2 & 10 & & 15 & & $\mathrm{Op}, \mathrm{Zr}$ & \\
\hline $\mathrm{EF}-15$ & 25 & 19 & 28 & & & 10 & 9 & & 8 & & & \\
\hline $\mathrm{EF}-23$ & 18 & 25 & 26 & & & 6 & 6 & & 18 & & $\mathrm{Op}, \mathrm{Zr}$ & \\
\hline AM-16A & 17 & 24 & 34 & & & 12 & 7 & & 5 & & $\mathrm{Op}, \mathrm{Zr}$ & \\
\hline AM-29A & 19 & 12 & 50 & & & 8 & 6 & & 4 & & & \\
\hline$E F-18 C^{a}$ & 27 & 24 & 39 & & & 5 & $\operatorname{tr}$ & & 4 & & Op, Zr & \\
\hline $\mathrm{EF}-16$ & 25 & 20 & 21 & & & 15 & 9 & & 9 & & Op & \\
\hline EF-21 & 26 & 24 & 20 & & & 4 & $\operatorname{tr}$ & & 25 & & $\mathrm{Op}, \mathrm{Zr}$ & \\
\hline AM-06C & 28 & 20 & 22 & & & 6 & 6 & & 16 & & $\mathrm{Op}, \mathrm{Zr}$ & \\
\hline AM-10B & 30 & 33 & 11 & & & 6 & 4 & & 15 & & Op & \\
\hline AM-17A & 21 & 33 & 10 & & & 18 & 8 & & 9 & & Op & \\
\hline AM-19B & 29 & 15 & 15 & & & 10 & 10 & & 20 & & Op & \\
\hline AM-19C & 15 & 36 & 11 & & & 6 & 6 & & 25 & & Op & \\
\hline AM-23A & 23 & 35 & 16 & & & 7 & 8 & & 10 & & Op & \\
\hline AM-30A & 20 & 15 & 35 & & & 8 & 10 & & 8 & & & \\
\hline AM-34A & 30 & 18 & 36 & & & 3 & 3 & & 9 & & $\mathrm{Op}, \mathrm{Zr}$ & \\
\hline AM-34B & 24 & 25 & 4 & & & 15 & 14 & & 18 & & & \\
\hline
\end{tabular}

Abbreviations follow Kretz (1983), plus Mp for mesoperthite and Or for orthoclase. $\mathrm{Tr}=\operatorname{traces}$.

a Datation $\mathrm{Sm} / \mathrm{Nd}$.

b Datation $\mathrm{Sm} / \mathrm{Nd}$ and $\mathrm{Zr}$.

some points very close to the quartz monzonite and quartz syenite fields (Table 1, Fig. 3).

\section{Geochemistry}

The most representative fresh samples were selected for geochemical determinations on both granulitic and granitic rocks. Whole-rock analyses are given in Tables 2 and 3 and, given that water content is generally low, they are presented on an anhydrous basis with iron expressed as $\mathrm{Fe}_{2} \mathrm{O}_{3}{ }^{*}=\mathrm{Fe}_{2} \mathrm{O}_{3}+1.111^{*} \mathrm{FeO}$.

\subsection{Bravo and Tanquinho granulites}

All granulites have sub-alkaline affinities in the $\mathrm{Na}_{2} \mathrm{O}+\mathrm{K}_{2} \mathrm{O}$ vs. $\mathrm{SiO}_{2}$ diagram (Fig. 4); in the AFM diagram of Irvine and Baragar (1971) (Fig. 5) all plot in the calc-alkaline field, which is corroborated by the $\mathrm{K}_{2} \mathrm{O}$ vs. $\mathrm{SiO}_{2}$ plot (Rickwood, 1989) where they fall in the medium K calc-alkaline field (Fig. 6). When reported in the normative An-Ab-Or triangle (Fig. 7, Barker, 1987), granulites mainly

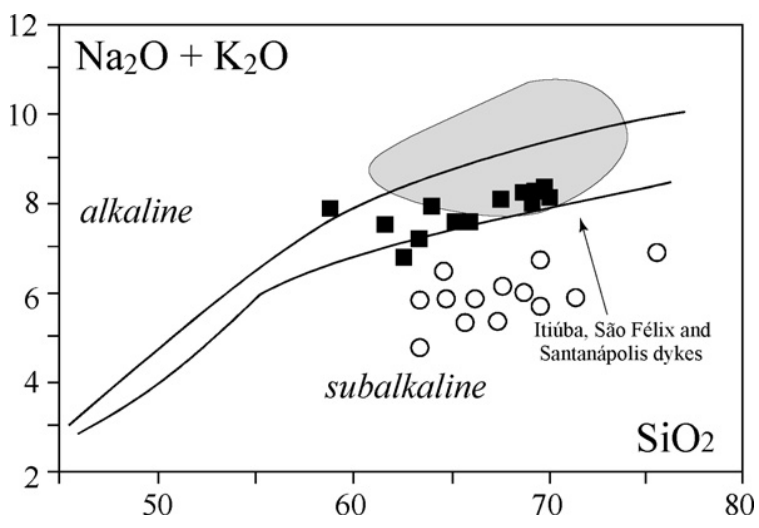

Fig. 4. Sub-alkaline affinities for the Bravo and Tanquinho granulitic country rocks and Bravo granite in the $\left(\mathrm{Na}_{2} \mathrm{O}+\mathrm{K}_{2} \mathrm{O}\right) \times \mathrm{SiO}_{2}$ diagram. Same symbols as Fig. 3 . 
Table 2

Geochemical data for the Tanquinho and Bravo granulitic country rocks

\begin{tabular}{|c|c|c|c|c|c|c|c|c|c|c|c|c|c|c|}
\hline \multirow{2}{*}{$\begin{array}{l}\text { Rock-type } \\
\text { Samples }\end{array}$} & \multicolumn{14}{|l|}{ Granulites } \\
\hline & $\mathrm{AM}-15 \mathrm{~A}^{\mathrm{a}}$ & EF-12A & EF-12B & $A M-20 A$ & AM-31A & $\mathrm{AM}-01 \mathrm{~A}^{\mathrm{a}}$ & AM-04A & LH-182 ${ }^{b}$ & $\mathrm{AM}-15 \mathrm{~B}^{\mathrm{a}}$ & AM-09A & AM-14A & AM-02A & $\mathrm{AM}-15 \mathrm{C}^{\mathrm{a}}$ & AM- $05 A^{b}$ \\
\hline $\mathrm{SiO}_{2}$ & 63.57 & 63.66 & 64.71 & 65.90 & 66.34 & 69.20 & 67.82 & 67.69 & 67.70 & 67.96 & 68.82 & 69.65 & 71.42 & 71.50 \\
\hline $\mathrm{TiO}_{2}$ & 0.44 & 0.83 & 0.73 & 0.55 & 0.49 & 0.13 & 0.47 & 0.42 & 0.44 & 0.40 & 0.44 & 0.44 & 0.22 & 0.25 \\
\hline $\mathrm{Al}_{2} \mathrm{O}_{3}$ & 15.62 & 17.12 & 16.66 & 15.72 & 16.33 & 16.00 & 16.78 & 17.13 & 16.55 & 15.86 & 15.32 & 13.50 & 14.41 & 15.00 \\
\hline $\mathrm{Fe}_{2} \mathrm{O}_{3}$ & 5.64 & 6.72 & 5.28 & 6.43 & 5.57 & 4.10 & 3.93 & 2.81 & 3.73 & 4.02 & 3.73 & 4.43 & 3.63 & 3.50 \\
\hline $\mathrm{MnO}$ & 0.11 & 0.13 & 0.10 & 0.17 & 0.18 & 0.06 & 0.15 & 0.01 & 0.08 & 0.13 & 0.09 & 0.14 & 0.03 & 0.10 \\
\hline MgO & 3.22 & 1.71 & 3.43 & 2.12 & 2.12 & 2.00 & 2.09 & 0.74 & 1.61 & 1.51 & 1.51 & 2.42 & 2.01 & 2.50 \\
\hline $\mathrm{CaO}$ & 6.35 & 3.73 & 2.62 & 3.63 & 3.02 & 2.80 & 2.61 & 3.63 & 4.44 & 3.91 & 3.93 & 2.62 & 2.42 & 2.00 \\
\hline $\mathrm{Na}_{2} \mathrm{O}$ & 3.83 & 4.43 & 3.84 & 3.83 & 3.93 & 3.50 & 4.19 & 5.44 & 4.24 & 3.90 & 3.83 & 4.43 & 3.02 & 3.00 \\
\hline $\mathrm{K}_{2} \mathrm{O}$ & 1.01 & 1.41 & 2.62 & 1.51 & 1.93 & 2.15 & 1.88 & 2.01 & 1.11 & 2.22 & 2.22 & 2.22 & 2.82 & 2.83 \\
\hline $\mathrm{P}_{2} \mathrm{O}_{5}$ & 0.21 & 0.26 & 0.01 & 0.14 & 0.09 & 0.06 & 0.08 & 0.12 & 0.10 & 0.09 & 0.11 & 0.15 & 0.02 & 0.02 \\
\hline Total & 100.00 & 100.00 & 100.00 & 100.00 & 100.00 & 100.00 & 100.00 & 100.00 & 100.00 & 100.00 & 100.00 & 100.00 & 100.00 & 100.00 \\
\hline $\mathrm{K}_{2} \mathrm{O} / \mathrm{Na}_{2} \mathrm{O}$ & 0.26 & 0.32 & 0.68 & 0.39 & 0.49 & 0.61 & 0.45 & 0.37 & 0.26 & 0.57 & 0.58 & 0.50 & 0.93 & 0.71 \\
\hline Mg\# & 53 & 34 & 56 & 40 & 43 & 49 & 51 & 34 & 46 & 43 & 45 & 52 & 52 & 45 \\
\hline $\mathrm{Cr}$ & 270 & 56.41 & 50 & 85 & 91 & & 53 & 30 & 65.58 & 77.29 & 57.44 & 66 & 49.20 & 52 \\
\hline $\mathrm{Ni}$ & 103 & 33.24 & 31 & 45 & 40 & & 21 & $<5$ & 35.31 & 36.14 & 30.23 & 38 & & 20 \\
\hline Co & 26 & 29.21 & 27 & 33 & 26 & & 16 & & 23.10 & 25.09 & 22.17 & 25 & & 16 \\
\hline V & 97 & 80.58 & 81 & 84 & 67 & 12 & 10 & & 53.47 & 41.15 & 42.32 & 50 & 8 & $<10$ \\
\hline $\mathrm{Cu}$ & 11 & 8.06 & 8 & 14 & 13 & & 8 & & 9.08 & 7.03 & 5.04 & 10 & & 7 \\
\hline $\mathrm{Rb}$ & 17 & 42.31 & 64 & 25 & 49 & 43 & 90 & 30 & 16.14 & 41.15 & 74.57 & 119 & 19 & 89 \\
\hline $\mathrm{Ba}$ & 454 & 670.00 & 796 & 909 & 547 & 956 & 1230 & 2000 & 413.65 & 814.06 & 753.73 & 1006 & 572 & 1225 \\
\hline $\mathrm{Sr}$ & 634 & 715.17 & 382 & 571 & 513 & 394 & 354 & 482 & 743.56 & 510.92 & 454.45 & 333 & 275 & 353 \\
\hline $\mathrm{Nb}$ & 7 & 14.10 & 10 & 6 & 11 & 6 & 9 & & & 9.03 & 8.06 & 17 & 5 & 7 \\
\hline $\mathrm{Zr}$ & 85 & 289.09 & 215 & 118 & 149 & 131 & 295 & 198 & 132.17 & 139.52 & 186.42 & 228 & 255 & 294 \\
\hline $\mathrm{Y}$ & 12 & 25.18 & 10 & 3 & 14 & 5 & 3 & $<10$ & & & & 19 & 5 & $<3$ \\
\hline Th & $<5$ & 11.08 & 23 & 19 & 10 & 24 & 5 & & & & & 27 & 35 & $<5$ \\
\hline $\mathrm{La}$ & 67.55 & 67.78 & 51.00 & 46.00 & & 24.58 & 39.40 & 24.40 & 17.42 & 20.56 & 39.28 & & 61.90 & 39.31 \\
\hline $\mathrm{Ce}$ & 102.61 & 144.04 & 117.21 & 90.55 & & 41.29 & 60.00 & 32.30 & 30.51 & 35.7 & 62.25 & & 94.22 & 59.04 \\
\hline $\mathrm{Nd}$ & 33.11 & 47.54 & 39.00 & 32.48 & & 12.65 & 21.00 & 14.00 & 9.60 & 14.99 & 21.66 & & 25.52 & 20.59 \\
\hline $\mathrm{Sm}$ & 6.56 & 7.41 & 6.42 & 4.48 & & 2.12 & 1.58 & 2.03 & 1.18 & 1.41 & 2.13 & & 4.26 & 1.57 \\
\hline $\mathrm{Eu}$ & 1.97 & 1.42 & 1.14 & 1.05 & & 0.59 & 1.20 & 0.77 & 0.60 & 0.72 & 0.95 & & 1.26 & 1.19 \\
\hline Gd & 3.75 & 4.46 & 3.76 & 2.39 & & 1.26 & 1.32 & 1.43 & 0.98 & 1.36 & 1.39 & & 2.36 & 1.32 \\
\hline Dy & 2.48 & 2.52 & 1.94 & 1.16 & & 0.64 & 0.84 & 0.94 & 0.52 & 0.75 & 1.01 & & 0.98 & 0.83 \\
\hline Ho & 0.45 & 0.43 & 0.34 & 0.20 & & 0.11 & 0.16 & 0.14 & 0.10 & 0.15 & 0.15 & & 0.16 & 0.16 \\
\hline $\mathrm{Er}$ & 85 & 0.83 & 0.67 & 0.40 & & 0.27 & 0.38 & 0.36 & 0.24 & 0.34 & 0.38 & & 0.29 & 0.37 \\
\hline $\mathrm{Yb}$ & 3.36 & 0.55 & 0.34 & 0.25 & & 0.20 & 0.36 & 0.40 & 0.17 & 0.32 & 0.31 & & 0.18 & 0.36 \\
\hline $\mathrm{Lu}$ & 0.07 & 0.08 & 0.05 & 0.04 & & 0.03 & 0.05 & 0.07 & 0.04 & 0.05 & 0.05 & & 0.02 & 0.06 \\
\hline
\end{tabular}

a Datation Sm-Nd.

b Datation Sm-Nd and Zr.

plot in the tonalite and granodiorite fields with only two points in the trondhjemite field. These characteristics are present in typical Archaean TTG even though the latter are generally more trondhjemitic (Martin, 1987; Martin and Moyen, 2002). Moyen et al.

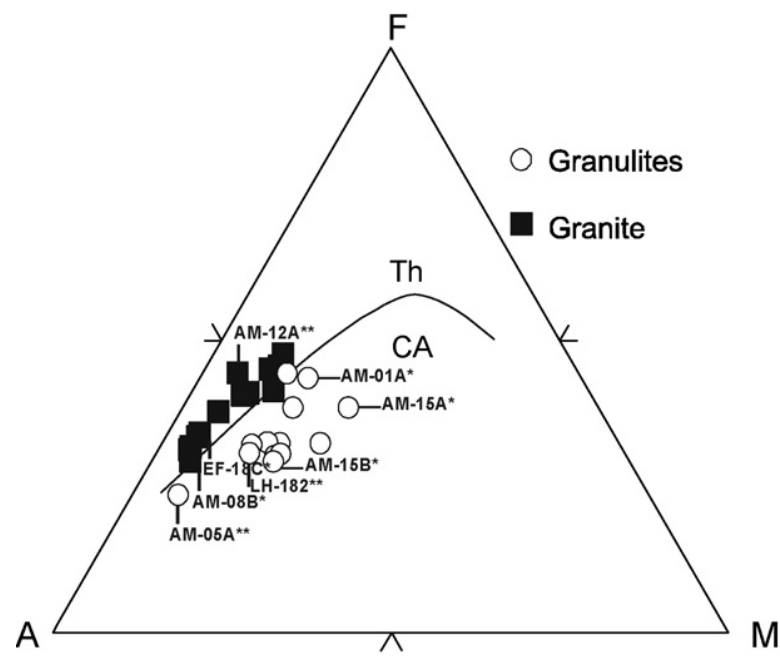

Fig. 5. A-F-M triangle (Irvine and Baragar, 1971) showing the calc-alkaline nature of the two groups of rocks. Th, tholeiite; CA, calc-alkaline. $\left({ }^{*}\right)$ Analysed for Sm/Nd; $\left.{ }^{(* *}\right)$ analysed for $\mathrm{Sm} / \mathrm{Nd}$ and $\mathrm{Zr}$ ages.
(2003) show, however, that at the end of Archaean times, some TTG were enriched (in $\mathrm{K}$ for instance) when compared with average TTG; they referred to them as "enriched TTG". The $\mathrm{CaO}-\mathrm{Na}_{2} \mathrm{O}-\mathrm{K}_{2} \mathrm{O}$ triangle (Fig. 8) shows that all granulites plot in the fields of both TTG and enriched TTG. Most granulites have A/CNK values greater than 1, thus pointing to their peraluminous character (Fig. 9). From this point of view, they totally differ from typical TTG whose average $\mathrm{A} / \mathrm{CNK}=1$.

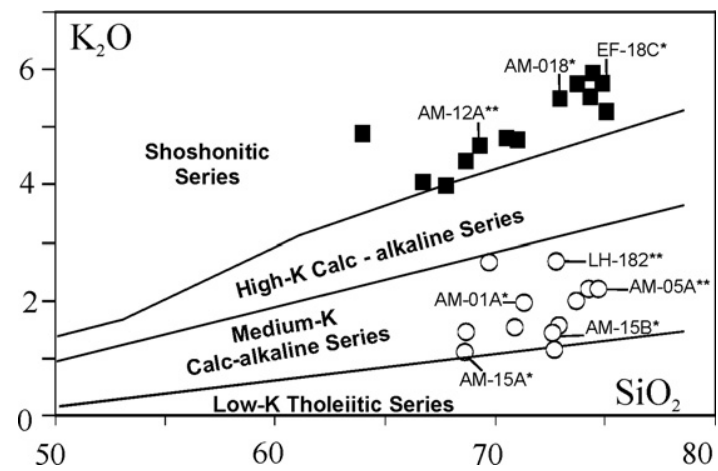

Fig. 6. Rickwood (1989) diagram showing the calk-alkaline medium-K trend for the Bravo and Tanquinho granulitic rocks and the shoshonitic trend for the Bravo Granite. $\left({ }^{*}\right)$ Datation $\mathrm{Sm} / \mathrm{Nd}$; $\left(^{* *}\right)$ datation $\mathrm{Sm} / \mathrm{Nd}$ and $\mathrm{Zr}$. 
Table 3

Geochemical data for the Bravo granite

\begin{tabular}{|c|c|c|c|c|c|c|c|c|c|c|c|c|c|}
\hline \multirow[t]{2}{*}{ Samples } & \multicolumn{13}{|c|}{ Rock-type: Bravo granite } \\
\hline & AM-33A & AM-27A & AM-26A & $\mathrm{AM}-12 \mathrm{~A}^{\mathrm{a}}$ & AM-14B & AM-25A & EF-23 & AM-16A & AM-01B ${ }^{b}$ & AM-29A & $E F-18 C^{b}$ & EF-16 & EF-21 \\
\hline $\mathrm{SiO}_{2}$ & 58.89 & 61.71 & 62.67 & 63.63 & 64.39 & 65.51 & 65.93 & 67.89 & 68.72 & 69.30 & 69.46 & 69.82 & 69.99 \\
\hline $\mathrm{TiO}_{2}$ & 2.43 & 1.61 & 1.51 & 1.61 & 1.22 & 1.32 & 1.31 & 1.01 & 1.29 & 1.01 & 0.81 & 0.75 & 0.77 \\
\hline $\mathrm{Al}_{2} \mathrm{O}_{3}$ & 14.67 & 14.22 & 14.41 & 13.99 & 14.56 & 13.96 & 14.13 & 13.54 & 13.99 & 15.02 & 13.61 & 14.04 & 14.16 \\
\hline $\mathrm{Fe}_{2} \mathrm{O}_{3}$ & 7.85 & 8.69 & 8.42 & 7.95 & 7.08 & 7.33 & 6.56 & 5.96 & 4.93 & 4.00 & 5.14 & 4.53 & 4.52 \\
\hline $\mathrm{MnO}$ & 0.19 & 0.12 & 0.19 & 0.12 & 0.14 & 0.15 & 0.00 & 0.12 & 0.06 & 0.09 & 0.11 & 0.00 & 0.00 \\
\hline $\mathrm{MgO}$ & 2.02 & 1.81 & 1.61 & 1.51 & 1.31 & 0.76 & 1.11 & 0.80 & 0.62 & 0.70 & 0.63 & 0.60 & 0.57 \\
\hline $\mathrm{CaO}$ & 5.06 & 3.73 & 4.03 & 3.62 & 3.23 & 3.06 & 3.13 & 2.42 & 2.05 & 1.62 & 1.81 & 1.82 & 1.72 \\
\hline $\mathrm{Na}_{2} \mathrm{O}$ & 3.04 & 3.43 & 2.72 & 2.72 & 3.13 & 2.65 & 2.73 & 2.53 & 2.41 & 2.44 & 2.32 & 2.53 & 2.83 \\
\hline $\mathrm{K}_{2} \mathrm{O}$ & 4.86 & 4.03 & 3.93 & 4.43 & 4.65 & 4.79 & 4.75 & 5.46 & 5.73 & 5.49 & 5.95 & 5.76 & 5.26 \\
\hline $\mathrm{P}_{2} \mathrm{O}_{5}$ & 0.99 & 0.65 & 0.51 & 0.42 & 0.29 & 0.47 & 0.35 & 0.27 & 0.20 & 0.33 & 0.16 & 0.15 & 0.18 \\
\hline Total & 100.00 & 100.00 & 100.00 & 100.00 & 100.00 & 100.00 & 100.00 & 100.00 & 100.00 & 100.00 & 100.00 & 100.00 & 100.00 \\
\hline $\mathrm{K}_{2} \mathrm{O} / \mathrm{Na}_{2} \mathrm{O}$ & 1.60 & 1.17 & 1.44 & 1.63 & 1.49 & 1.81 & 1.74 & 2.16 & 2.38 & 2.25 & 2.56 & 2.28 & 1.86 \\
\hline $\mathrm{Mg \#}$ & 34 & 29 & 27 & 27 & 27 & 17 & 25 & 21 & 20 & 26 & 19 & 21 & 20 \\
\hline$(\mathrm{Na}+\mathrm{K}+2 \mathrm{Ca}) /(\mathrm{Al} \times \mathrm{Si})$ & 1.99 & 1.61 & 1.56 & 1.51 & 1.41 & 1.46 & 1.35 & 1.23 & 1.09 & 0.92 & 1.07 & 1.04 & 1.01 \\
\hline $\mathrm{FeO}^{*} / \mathrm{MgO}$ & 3.49 & 4.31 & 4.70 & 4.74 & 4.85 & 8.64 & 5.32 & 6.72 & 7.11 & 5.14 & 7.40 & 6.83 & 7.14 \\
\hline A/CNK & 0.75 & 0.85 & 0.90 & 0.88 & 0.91 & 0.92 & 0.82 & 0.94 & 1.01 & 1.16 & 1.00 & 1.03 & 1.05 \\
\hline $\mathrm{Cr}$ & 69 & 73 & 87 & 42 & 62 & 62 & 38 & 56 & & 59 & 45 & 41 & 39 \\
\hline $\mathrm{Ni}$ & 42 & 34 & 38 & 28 & 29 & 27 & 50 & 27 & & 28 & 30 & 40 & 38 \\
\hline Co & 43 & 30 & 33 & 26 & 31 & 29 & 37 & 22 & & 22 & 18 & 30 & 28 \\
\hline $\mathrm{V}$ & 123 & 86 & 97 & 83 & 98 & 51 & & 64 & 38 & 71 & 43 & & \\
\hline $\mathrm{Cu}$ & 26 & 26 & 15 & 17 & 17 & 11 & 10 & 13 & & 17 & 12 & 10 & 10 \\
\hline $\mathrm{Rb}$ & 79 & 107 & 78 & 115 & 95 & 105 & 118 & 143 & 181 & 174 & 196 & 166 & 146 \\
\hline $\mathrm{Ba}$ & 1668 & 1943 & 1859 & 1598 & 2381 & 1725 & 1785 & 1544 & 1611 & 2237 & 1313 & 1488 & 2091 \\
\hline $\mathrm{Sr}$ & 467 & 332 & 473 & 353 & 379 & 255 & 359 & 283 & 270 & 356 & 233 & 236 & 278 \\
\hline $\mathrm{Nb}$ & 53 & 52 & 35 & 38 & 33 & 41 & 26 & 35 & 41 & 17 & 30 & 16 & 11.1 \\
\hline $\mathrm{Hf}$ & 15 & 24 & 20 & 16 & 23 & 17 & 24 & 19 & 16 & 13 & 21 & 18 & 16.18 \\
\hline $\mathrm{Zr}$ & 631 & 1037 & 871 & 670 & 969 & 717 & 856 & 816 & 734 & 557 & 885 & 786 & 704 \\
\hline $\mathrm{Y}$ & 75 & 154 & 78 & 79 & 48 & 62 & 65 & 62 & 64 & 20 & 79 & 58 & 24 \\
\hline Th & $<5$ & $<5$ & $<5$ & 15 & $<5$ & $<5$ & 9 & 16 & 35 & 113 & 34 & 15 & $>5$ \\
\hline $\mathrm{La}$ & 118.60 & 162.10 & 108.70 & 249.50 & 250.30 & & 140.40 & 132.30 & 153.40 & 120.50 & 321.10 & & \\
\hline $\mathrm{Ce}$ & 271.40 & 501.30 & 256.90 & 410.80 & 405.30 & & 291.90 & 293.30 & 326.80 & 255.90 & 531.20 & & \\
\hline $\mathrm{Nd}$ & 99.95 & 217.70 & 105.20 & 234.07 & 200.40 & & 120.90 & 100.20 & 115.00 & 86.07 & 215.18 & & \\
\hline $\mathrm{Sm}$ & 19.02 & 38.24 & 17.78 & 25.73 & 3.80 & & 19.12 & 15.71 & 17.53 & 11.77 & 19.48 & & \\
\hline $\mathrm{Eu}$ & 2.91 & 4.15 & 2.59 & 4.74 & 3.10 & & 3.03 & 2.19 & 2.54 & 1.53 & 2.75 & & \\
\hline $\mathrm{Gd}$ & 13.24 & 26.53 & 11.18 & 22.47 & 22.15 & & 13.32 & 10.05 & 11.39 & 6.59 & 18.16 & & \\
\hline Dy & 9.69 & 19.04 & 8.16 & 18.30 & 10.12 & & 10.97 & 7.35 & 7.96 & 3.04 & 11.00 & & \\
\hline Ho & 1.70 & 3.55 & 1.49 & 3.52 & 2.19 & & 2.06 & 1.38 & 1.48 & 0.52 & 2.06 & & \\
\hline Er & 3.93 & 8.26 & 3.30 & 8.78 & 3.10 & & 4.88 & 3.24 & 3.39 & 0.93 & 4.82 & & \\
\hline $\mathrm{Yb}$ & 3.33 & 4.66 & 2.20 & 5.99 & 4.30 & & 3.33 & 1.99 & 2.74 & 0.59 & 3.33 & & \\
\hline $\mathrm{Lu}$ & 0.46 & 0.55 & 0.33 & 0.61 & 0.40 & & 0.41 & 0.27 & 0.40 & 0.09 & 0.36 & & \\
\hline
\end{tabular}

\section{FeO*, Fe total.}

a Datation Sm-Nd and Zr.

batation Sm-Nd. 


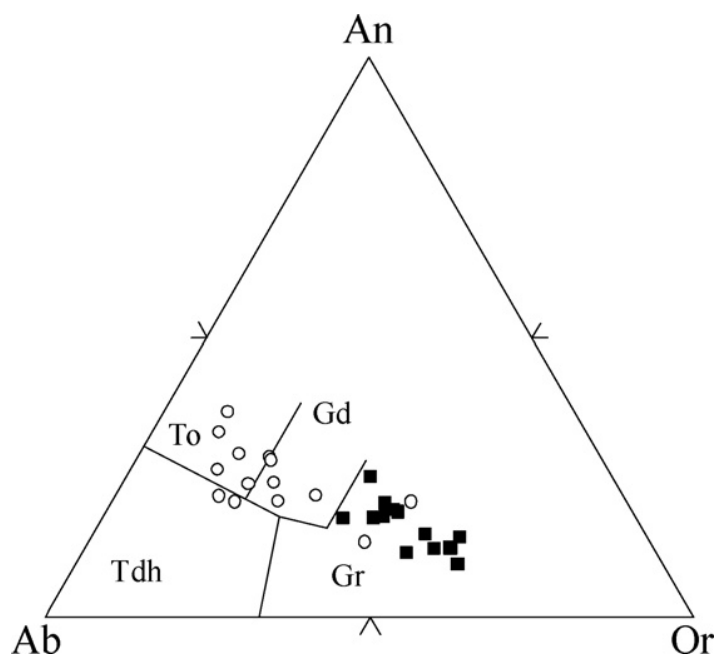

Fig. 7. An-Ab-Or triangle of Barker, 1987, showing the Bravo and Tanquinho granulitic country rocks plotting mainly in the tonalite fields and the Bravo granite in the granitic field. Same symbols of Fig. 3.

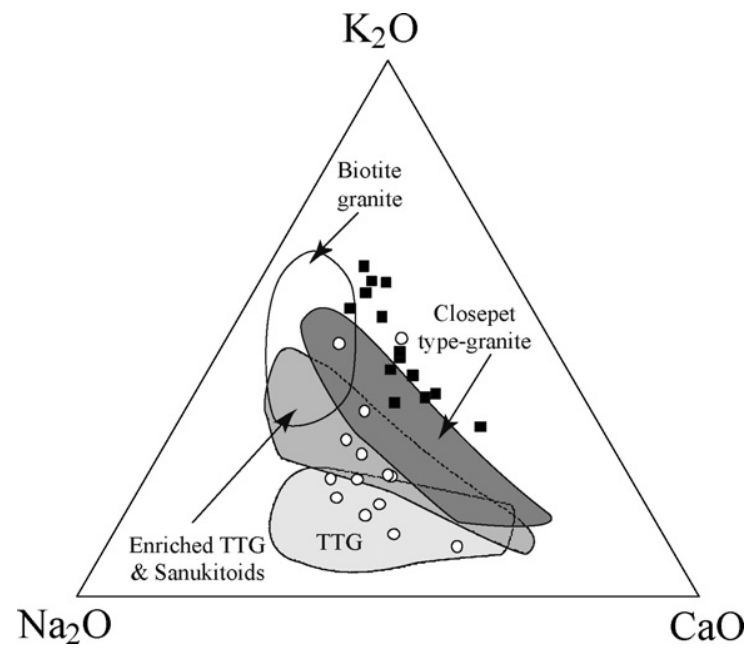

Fig. 8. The $\mathrm{CaO}-\mathrm{Na}_{2} \mathrm{O}-\mathrm{K}_{2} \mathrm{O}$ triangle of Moyen et al. (2003) showing the Bravo and Tanquinho granulitic country rocks plotting in the field of both TTG and enriched TTG. Same symbols of Fig. 3.

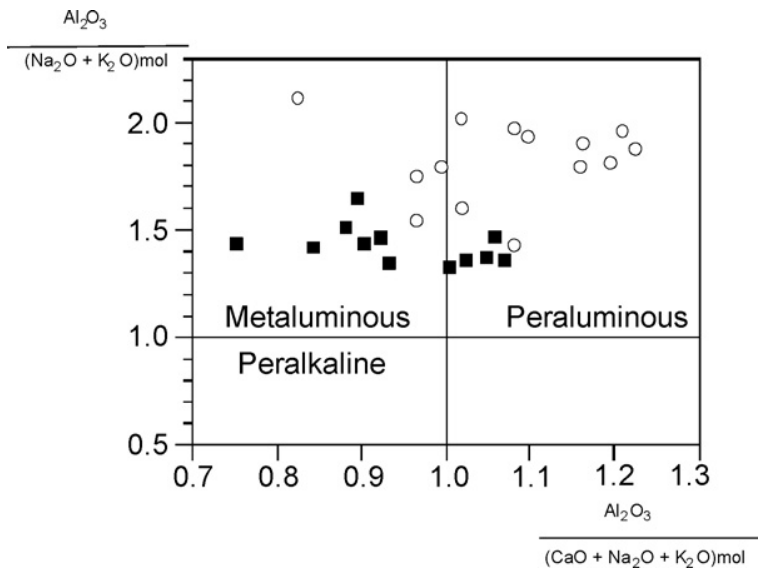

Fig. 9. Shand (1950) diagram with plot of and Bravo and Tanquinho granulitic country rocks and the Bravo Granite. Same symbols of Fig. 3.
In Harker diagrams for major elements (Fig. 10), where $\mathrm{SiO}_{2}$ is considered as differentiation index, granulites show differentiation trends even if data slightly scatter around these trends. All elements are negatively correlated with $\mathrm{SiO}_{2}$, except for $\mathrm{K}_{2} \mathrm{O}$ that has a positive correlation. Trends for trace elements (Fig. 11) allow the definition of incompatible (e.g. Rb, Ba, and also Y) and compatible (e.g. Sr and V) elements. Other trace elements (e.g. $\mathrm{Nb}, \mathrm{Cr}$ and $\mathrm{Ni}$ ) do not show significant variation during differentiation.

Chondrite-normalized REE patterns (Sun, 1982) fall into two groups (Fig. 12). The first (Fig. 12a) has strongly fractionated patterns with high LREE contents $\left(\operatorname{La}_{N}>100\right.$ ), very low HREE contents $\left(\mathrm{Yb}_{\mathrm{N}}<3\right)$, slight concavity at the HREE end, and no significant Eu anomaly. The second group (Fig. 12b) is slightly poorer in both LREE $\left(50<\mathrm{La}_{\mathrm{N}}<120\right)$ and HREE $\left(\mathrm{Yb}_{\mathrm{N}}<2\right)$. In addition, it possesses a significant positive Eu anomaly. The patterns of the first group are typical of Archaean TTG (Martin, 1986, 1987); the second group, even if rarer, is also known in Archaean TTG, mostly in late-Archaean examples (Martin, 1987; Moyen et al., 2003). These affinities are confirmed by the $(\mathrm{La} / \mathrm{Yb})_{\mathrm{N}} \mathrm{vs}$. $\mathrm{Yb}_{\mathrm{N}}$ diagram, where all granulites fall in the typical Archaean TTG field (Martin, 1986) (Fig. 13), and corroborate the interpretation drawn from the major element data. In the Nb vs. Y plot, they fall in the "Syn-Collisional Granite" field of Pearce et al. (1984), which is consistent with their slightly peraluminous character, even if this latter is not at all typical of Archaean TTG. (Fig. 14).

\subsection{The Bravo granite}

The Bravo granite composition strongly contrasts with that of the surrounding granulites. For instance, its iron content is greater than in granulites, whereas magnesium is lower, thus resulting in relatively low $\mathrm{Mg} \#$ in granite. Another consequence is that in an AFM triangle (Fig. 5) all granite data plot in the tholeiitic field (Kuno, 1968). In the $\mathrm{Na}_{2} \mathrm{O}+\mathrm{K}_{2} \mathrm{O}$ vs. $\mathrm{SiO}_{2}$ diagram (Fig. 4), the compositions of the Bravo granite plot between the limits drawn by Irvine and Baragar (1971) separating tholeiitic and alkaline rocks. The "alkalinity" is mainly due to high $\mathrm{K}_{2} \mathrm{O}$ contents (4.03-5.95) which makes the Bravo granite falling in the shoshonitic field of the $\mathrm{K}_{2} \mathrm{O}$ vs. $\mathrm{SiO}_{2}$ plot (Fig. 6). Different from the granulites, the Bravo granite is mostly metaluminous with $\mathrm{A} / \mathrm{CNK}$ ranging from 0.75 to 1.07 (Fig. 9).

In the An-Ab-Or triangle (O'Connor, 1965), the Bravo granite falls in the granitic field, far from the Bravo and Tanquinho granulites (Fig. 7). The $\mathrm{K}_{2} \mathrm{O}-\mathrm{Na}_{2} \mathrm{O}-\mathrm{CaO}$ triangle (Fig. 8) leads to the same conclusion, the Bravo granite is K-rich and plots above the Closepettype and Archaean biotite granite fields (Moyen et al., 2003), and thus demonstrating that it has no affinity with the most typical Archaean granitoids.

In Harker diagrams for major elements (Fig. 10) the Bravo granite samples show sharp differentiation trends. As for the granulites, all major elements are negatively correlated with $\mathrm{SiO}_{2}$, except for $\mathrm{K}_{2} \mathrm{O}$ with a positive correlation. In the same diagrams, the behaviour of some of the trace elements (Fig. 11) contrasts with that observed in the granulites. In the granite, Ba and Sr have a compatible behaviour, which may point to feldspar fractionation. Another difference with granulites is displayed by $\mathrm{Nb}$ which is strongly fractionated in the Bravo granite. In addition, $Y$ contents are generally higher $(>40 \mathrm{ppm}$ and up to $80 \mathrm{ppm}$ ) than those in the granulites ( $5 \mathrm{ppm}<\mathrm{Y}<35 \mathrm{ppm}$ ), and $\mathrm{Y}$ is compatible in the granite but incompatible in the granulites.

REE patterns (Fig. 12c) are characterised by very high REE contents for both LREE $\left(376<\mathrm{La}_{\mathrm{N}}<1019\right)$ and HREE $\left(9.6<\mathrm{Yb}_{\mathrm{N}}<28.8\right)$. In addition, they display significant negative $\mathrm{Eu}$ anomalies that, together with the compatible behaviour of Sr (Fig. 11) argue in favour of feldspar differentiation. In the $(\mathrm{La} / \mathrm{Yb})_{\mathrm{N}} \mathrm{vs}$. $\mathrm{Yb}_{\mathrm{N}}$ diagram, all the Bravo granite compositions plot outside and far from the 

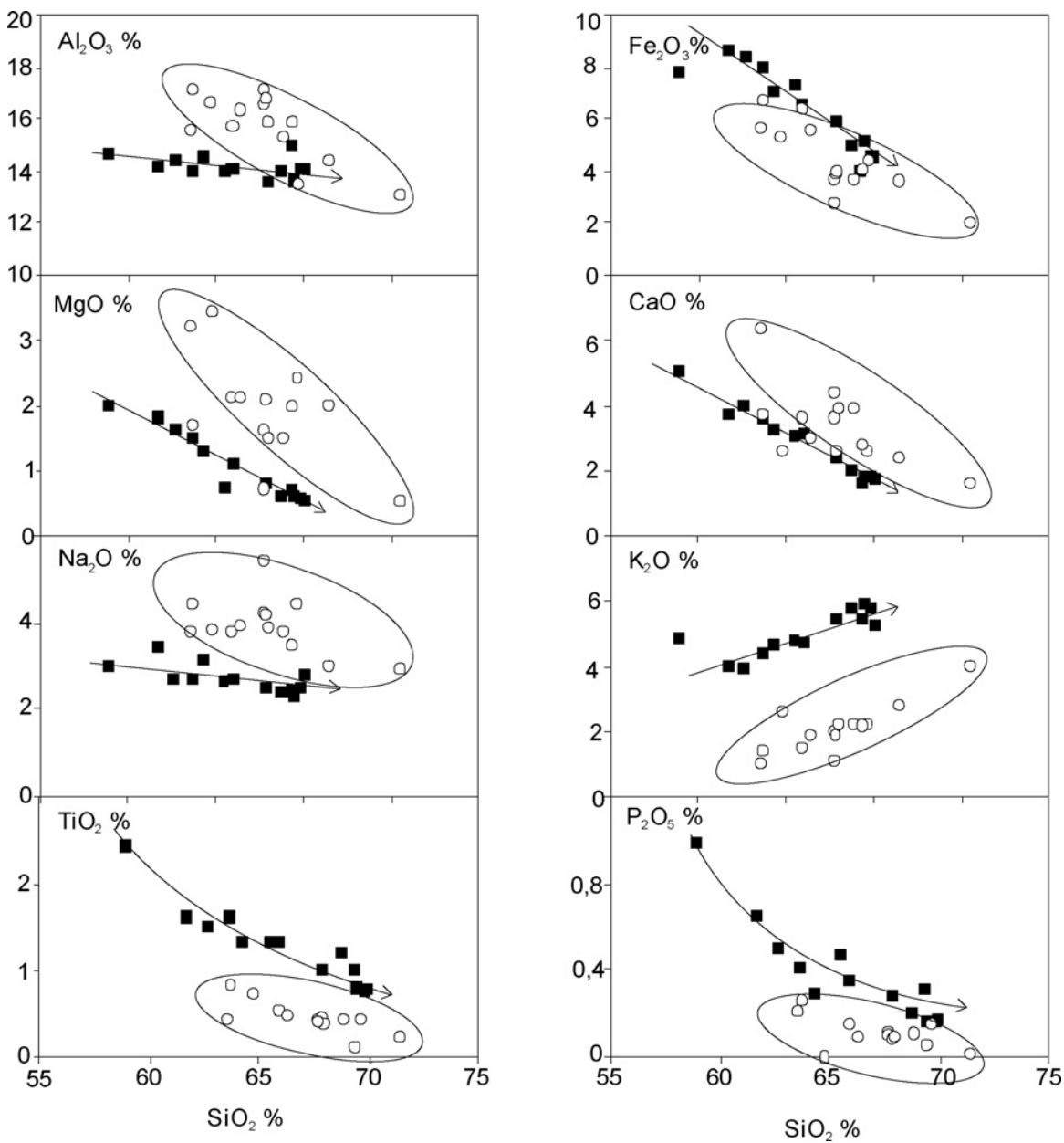

Fig. 10. Major elements in the Harker diagrams for the Bravo and Tanquinho granulitic country rocks and the Bravo Granite. Same symbols of Fig. 3.

Archaean TTG field (Martin, 1986). It must also be noted that they are not only different of Archaean TTG, but also of typical post-2.5 Ga calc-alkaline granites; they are too La-rich. Consequently, all the chemical aspects of both major and trace elements show that the Bravo granite is not at all a classical calc-alkaline pluton, but shows some affinities with alkaline magmas.

The A/CNK ratio ranges from 0.75 to 1.07 (Fig. 9), and compositions fall in the "Within Plate Granite" field in the Nb vs. Y diagram of Pearce et al. (1984) (Fig. 14). The vertical trend in a diagram using the logarithm of a compatible element such as $\mathrm{Rb}$ vs. the logarithm of an incompatible element such as $\mathrm{Nb}$ shows that the differentiation of the Bravo granite has been controlled by fractional crystallization mechanisms (Fig. 15). The Nb-Y-Ce diagram shows that the Bravo granite belongs to the A-2 type that is considered by Eby (1992) as resulting of the partial melting of granulites (Fig. 16).

\section{Petrogenetic discussion}

\subsection{The Bravo and Tanquinho granulites}

The granulites display some characteristics of Archaean TTG, and consequently, it can be tentatively assumed that they were generated through partial melting of hydrous basalt in the stability field of garnet (Martin, 1986, 1987; Defant and Drummond, 1990; Rapp and Watson, 1995). However, some of these TTG display an enriched character that Moyen et al. (2003) interpret as due to interaction with a mantle peridotite, as observed for instance in Closepet gran- ites (Fig. 8). This assumption is supported by the fact that these TTG display slightly higher $\mathrm{Mg} \#(40<\mathrm{Mg} \#<60)$ than in average typical TTG ( 45; Martin et al., 2005). Both TTG and enriched TTG, as well as Closepet-type granites and sanukitoids (Fig. 8) are believed to be generated in a subduction zone environment, where the subducted basalts are able to reach their solidus temperature before being dehydrated (see Moyen et al., 2003). The generated felsic magmas are able to interact with peridotite during their ascent through the mantle wedge. Even though TTG are known in Proterozoic terranes they are subordinate compared to Archaean examples. This does not provide any reliable proof that the protolith of granulites has an Archaean age, but nevertheless it appears consistent with the ages of these rocks (see later). In addition, some granulites are peraluminous with $\mathrm{A} / \mathrm{CNK}>1.1$, which is not at all a TTG characteristic. This characteristic, together with low $\varepsilon_{\mathrm{Nd}}(\sim-6$ at $2.07 \mathrm{Ga})$ could indicate an origin by partial melting of older TTG. Moderate degrees of melting of TTG would have not significantly modified the steep slope of REE patterns.

\subsection{The Bravo granite}

The Bravo granite has a composition very different from that of granulites, which also logically points to a different petrogenesis. Among the hypothesis proposed to account for A-2 granite genesis (Fig. 16), several refer to partial melting of lower crust from which melts have been previously extracted (Collins and Beams, 1982; Clemens and Holloway, 1996). Creaser et al. (1991) consider that 

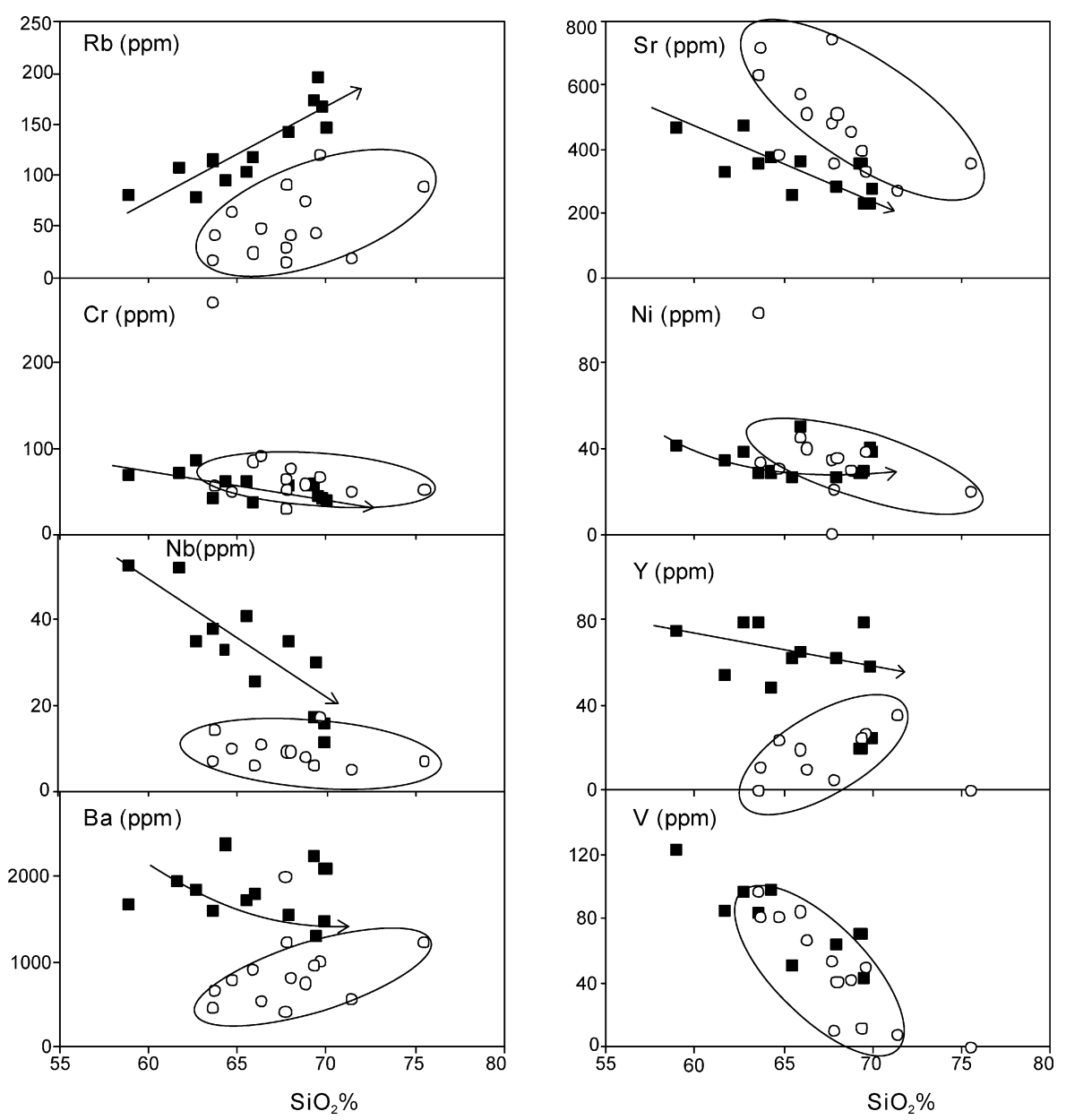

Fig. 11. Trace elements in the Harker diagrams for the Bravo and Tanquinho granulitic country rocks and the Bravo Granite. Same symbols of Fig. 3.

A-type granites could be generated by partial melting of tonalite or granodiorite. Eby (1992) considers that this could take place in a continental margin or island arc environment. Following this set of hypothesis, TTG-like granulites could have been the source of the Bravo granite (Fig. 16).

\subsubsection{First hypothesis}

The granulites display a compositional range from 63.57 to $71.50 \% \mathrm{SiO}_{2}$, while the range for the Bravo granite is from 58.89 to $69.99 \%$. In several Harker diagrams, the trends are more or less parallel trends. Partial melting of granulites, which are felsic rocks, should produce magmas whose composition is close to the granitic eutectic system, and a tighter, more homogeneous group would be expected. One could argue that after their genesis by partial melting of granulites, magmas could have evolved by fractional crystallisation. If generated magma has a sub-eutectic composition, a large fractional crystallization would not be able to develop. Moreover, in Bravo granite some samples (AM-33A, AM-27A, AM-26A) are $\mathrm{SiO}_{2}$-poorer and $\mathrm{Fe}_{2} \mathrm{O}_{3}$ and $\mathrm{TiO}_{2}$-richer than the granulites. It seems unrealistic to imagine that such "silica-poor" magmas could be produced by melting of $\mathrm{SiO}_{2}$-richer magmas.

\subsubsection{Second hypothesis}

Another possibility is evidenced by the fact that the Bravo granite, in the Q-A-P triangle of Streckeisen (1975) has a composition of syeno-granite with sample close to the quartz-monzonite and quartz-syenite fields (Fig. 3). Similar rocks are known in the area; indeed, several big syenitic massifs emplaced more or less at the same time in the close vicinity-Itiúba, Santanapolis and São Felix (Conceição, 1990, 1994, 1998; Rosa, 1994, 1998; Rosa et al., 2001; Oliveira et al., 2004). Obviously Bravo granite is not at all a syenite and for instance whereas the $\mathrm{SiO}_{2}$ content of syenites ranges between 49 and $58 \%$, it is always $>58 \%$ in Bravo. However, syenite massifs contain dykes, that are interpreted as cogenetic and which appear to be as silica-rich as the granite. In fact the syenites are interpreted as mainly consisting in cumulate with subordinate amounts of intercumulus liquid (Conceição, 1990). This author interprets the fine-grained dykes as preserved parts of the differentiated syenitic magma. The mineralogical composition (plagioclase, alkali feldspar, biotite and amphibole; Fig. 3) of dykes cutting the Itiúba, Santanápolis and São Felix syenites is similar to that of the Bravo granite; their $\mathrm{Na}_{2} \mathrm{O}+\mathrm{K}_{2} \mathrm{O}$ contents are alike (Fig. 4) showing that they also belong to A2-type magmas (Figs. 16 and 17). Figs. 18 and 19 compare the REE and trace elements compositions of the Bravo granite (grey field) with the composition of dykes from the Itiúba, Santanápolis and São Felix syenites. The patterns are very similar and especially, they show exactly the same strong negative anomalies ( $\mathrm{Nb}, \mathrm{Sr}, \mathrm{Ti}$, and partly $\mathrm{Eu}$ ). In addition the level of element abundance is similar, with only one exception: Bravo granite has very high $\mathrm{Zr}$ contents whereas these latter are lower in syenite dykes. In addition, the $\varepsilon_{\mathrm{Nd}}$ of Bravo granite at $2.07 \mathrm{Ga}(-6.3$ to -7.7$)$ is in the same range as Itiúba and Santanapolis syenites $(-3$ to -10$)$. The emplacement age of the Bravo granite is $2063 \pm 6$ Ma, whereas Itiúba is $2084 \pm 9 \mathrm{Ma}$ and São Felix, 2098 \pm 1 Ma old (Oliveira et al., 2004; Rosa et al., 2001). These ages are very close even if not similar. It seems that there was a major regional event of syen- 


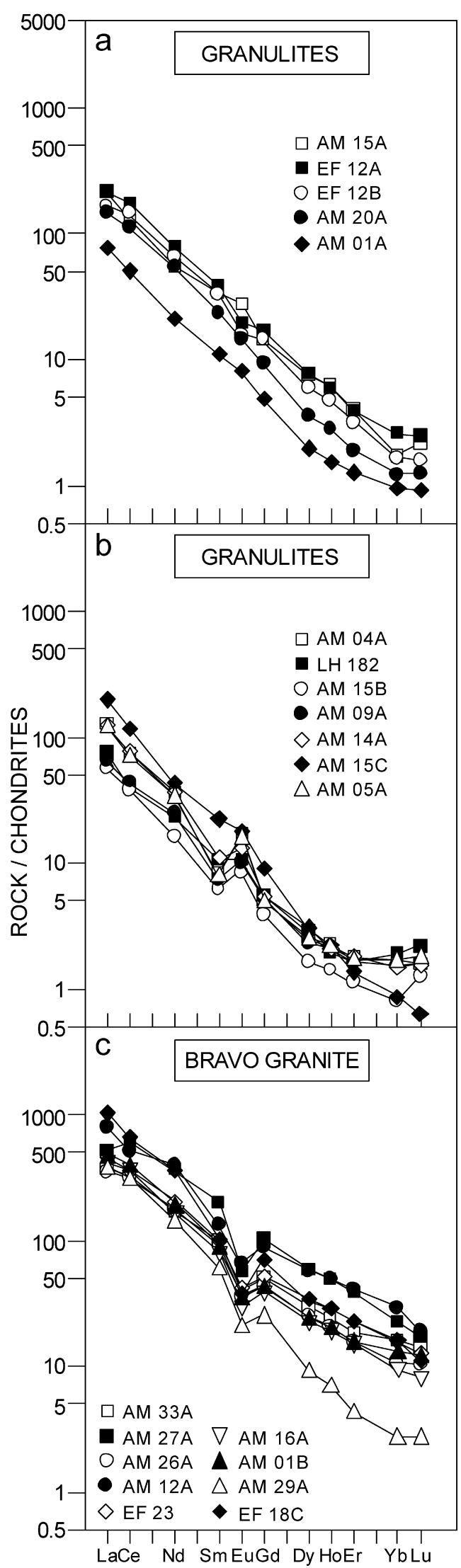

Fig. 12. REE patterns for the Bravo and Tanquinho granulitic country rocks and the Bravo Granite. See in the granulites two groups of patterns: the first one (a) do not has Eu anomaly and the other one (b) has significant positive Eu anomaly. Chondritenormalized REE patterns from Sun (1982).

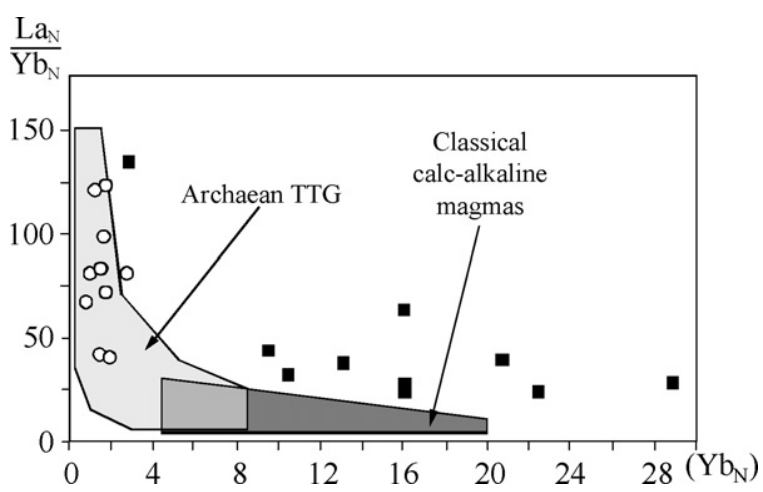

Fig. 13. $(\mathrm{La} / \mathrm{Yb})_{\mathrm{N}} \times \mathrm{Yb}_{\mathrm{N}}$ diagram, showing that all Bravo and Tanquinho granulites fall in the typical Archaean TTG field and the Bravo granite in the field of classical calc-alkaline magmas (Martin, 1986). Symbols are the same of Fig. 3.

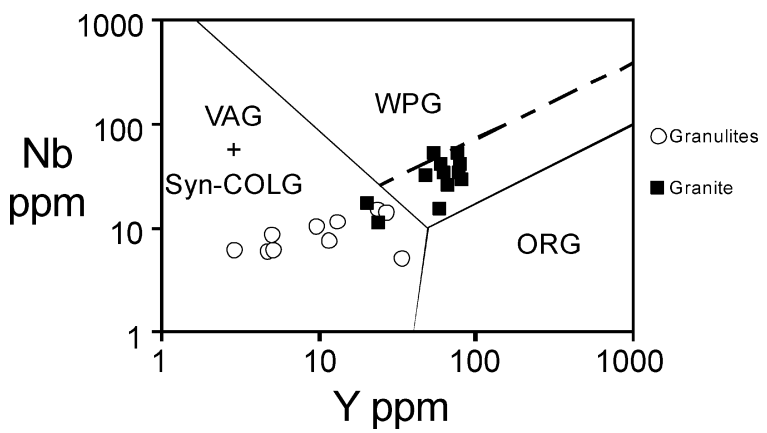

Fig. 14. Diagram $\mathrm{Nb} \times \mathrm{Y}$ for the Bravo and Tanquinho granulitic country rocks and the Bravo Granite. VAG, volcanic-arc granites; Syn COLG, syn-collisional granites; WPG, withing-plate granites; ORG, ocean-ridge granites. The broken line is the field boundary for ORG from anomalous ridges (Pearce et al., 1984).

ite emplacement between 2.090 and $2.060 \mathrm{Ga}$ in this part of the São Francisco craton (Rios, 2002). These syenites emplaced posttectonically in large shear-zones as a response to crustal thinning; Bravo granite also emplaced in a similar tectonic regional environment. It can also be supposed that, if the dykes are very late products of syenite evolution, the age difference between the Bravo granite and the Itiúba and São Felix syenites could reflect this high temperature $\left(900-1000^{\circ} \mathrm{C}\right)$ event (Green and Watson, 1982; Watson and Harrison, 1983) (Fig. 20).

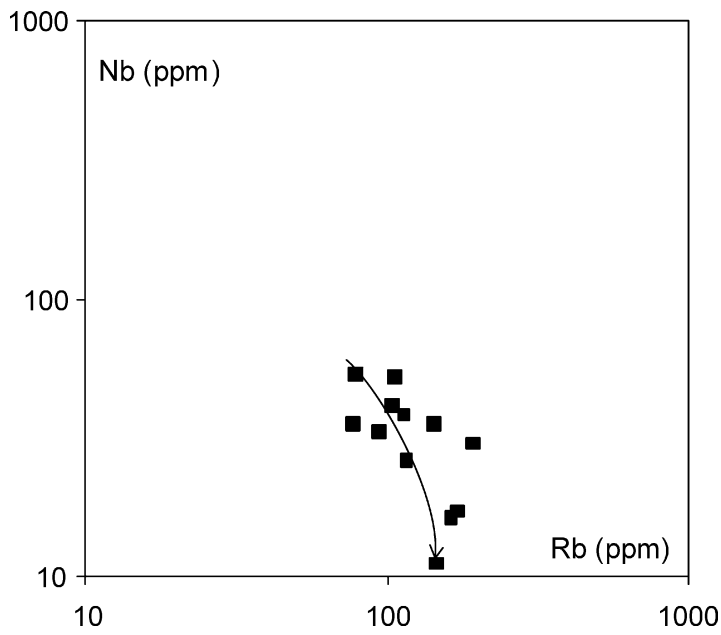

Fig. 15. $\mathrm{Nb} \times \mathrm{Rb}$ diagram showing a near vertical trend suggesting that Bravo granite was produced by fractional crystallization. 


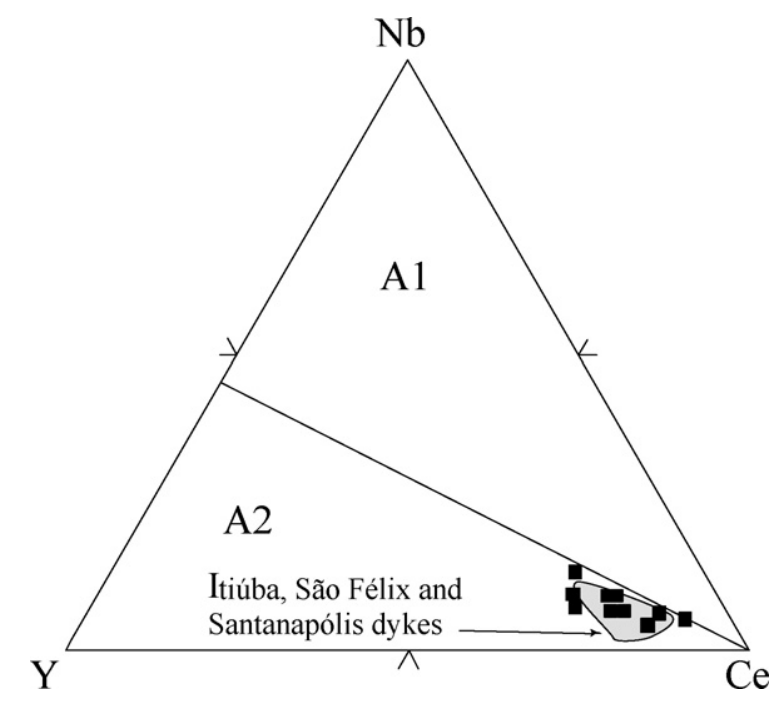

Fig. 16. The Nb-Y-Ce triangle of Eby (1992) showing the plot of the Bravo Granite in the A-2 type granite. A-1, granites of mantle source; A-2, granites of granulites fusion.

\section{Zircon dating and $\mathrm{Nd}$ isotopes}

One sample (AM-12A) of the Bravo granite and two of the surrounding granulites in the vicinity of Bravo (AM-05A) and Tanquinho (LH-182) villages were selected for zircon dating (Figs. 2 and 3). We performed in situ SHRIMP analyses at ANU, Canberra, Australia, and obtained TIMS evaporation ages at Géosciences Rennes, France. Nd isotope investigation on several whole-rock samples was also performed in order to constrain the origin of these rocks.

\subsection{Zircon dating of the Bravo granulite (AM-05A)}

Two major types of zircon are visible in sample AM-05A, one corresponds to elongated, subeuhedral, finely zoned, dark metamict crystals with corroded surfaces (grains 12 and 13, Fig. 21) and have probably a magmatic origin. The corresponding U-Pb SHRIMP data are discordant (Table 4, Fig. 21) and defined minimum ${ }^{207} \mathrm{~Pb} /{ }^{206} \mathrm{~Pb}$ ages of ca. 2.4 and $2.5 \mathrm{Ga}$ which indicate the presence of an Archaean component (probably $>2.5 \mathrm{Ga}$ ) in these zircons.

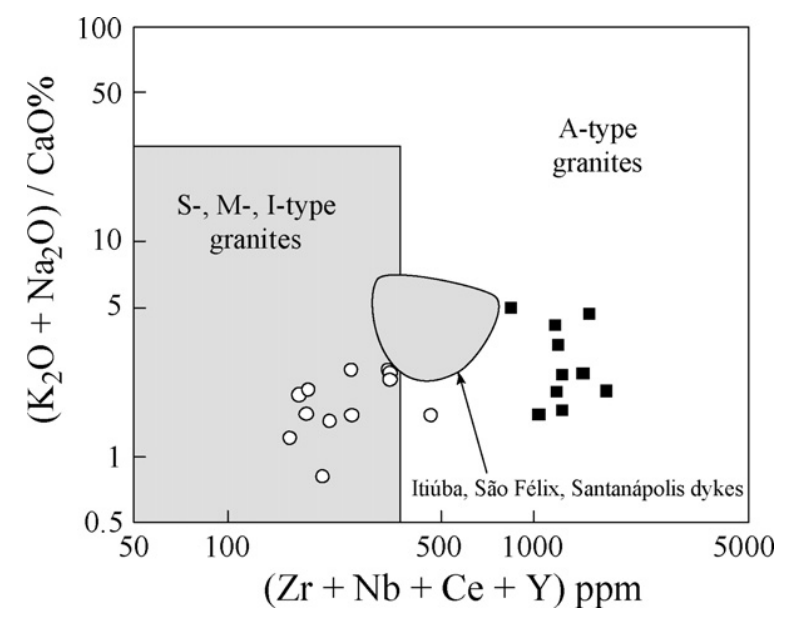

Fig. 17. $\mathrm{K}_{2} \mathrm{O}+\mathrm{Na}_{2} \mathrm{O} / \mathrm{CaO} \times(\mathrm{Zr}+\mathrm{Nb}+\mathrm{Ce}+\mathrm{Y})$ diagram showing that Bravo granite is included in the A-type granite field together with Itiuba syenite and São Felix and Santanápolis dykes.

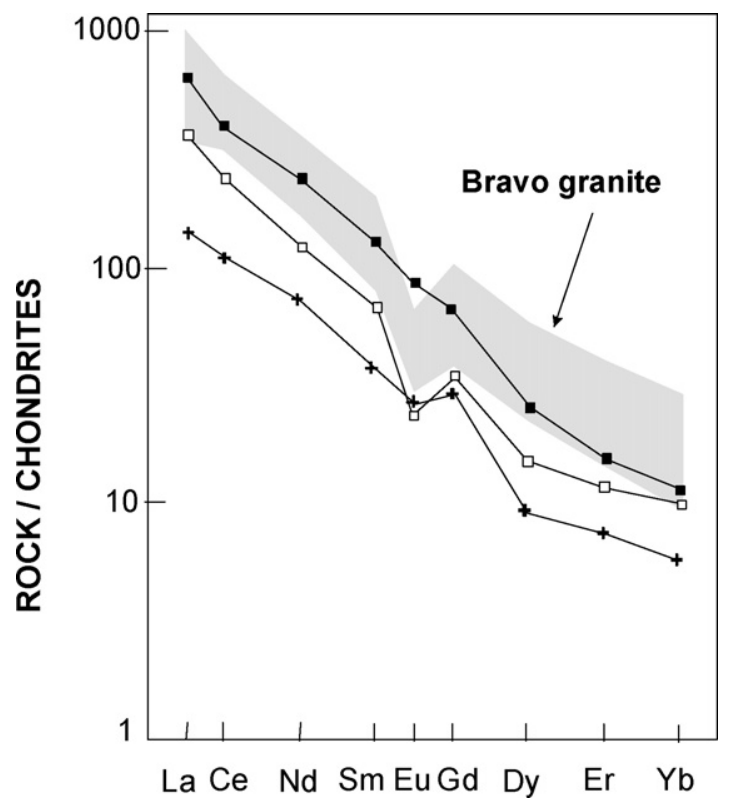

Fig. 18. Compared REE of the Bravo granite (grey field) with the composition of dykes from the Itiúba, Santanápolis and São Felix syenites. Chondrite-normalized REE patterns from Sun (1982).

A second type corresponds to clear, euhedral and elongated zircons (i.e. grains 6 and 10, Fig. 22) with a concentric zoning. They belong to the S18-S24 high temperature types of Pupin (1980) and are probably magmatic in origin. Some clear round grains may constitute a third type of zircons (grains 5 and 7 in Table 4), they are like zircons often observed in granulites but are not significantly different of the second type when Th and $U$ contents are considered. All $\mathrm{Th} / \mathrm{U}$ ratios of these last two types of zircon grains are relatively high as generally found for magmatic zircons and we found no low Th/U ratios $(<0.1)$ which are frequently encountered in granulite zircon. This similarity is confirmed by ages which are all sub-concordant and in a restricted range (Fig. 22). Taken together the nine analyses define an intercept at $2070 \pm 6 \mathrm{Ma}(\mathrm{MSWD}=0.42)$ and a mean ${ }^{207} \mathrm{~Pb} /{ }^{206} \mathrm{~Pb}$ age at $2064 \pm 6 \mathrm{Ma}(\mathrm{MSWD}=0.79)$. This set of zircons is probably related to a magmatic event at ca. $2.07 \mathrm{Ga}$ (with Achaean inheritance) possibly emplaced in granulite facies conditions. An alternative explanation would be to consider the $c a .2 .07 \mathrm{Ga}$ zircons as metamorphic and the age of the magmatic protolith older, this hypothesis seems unlikely.

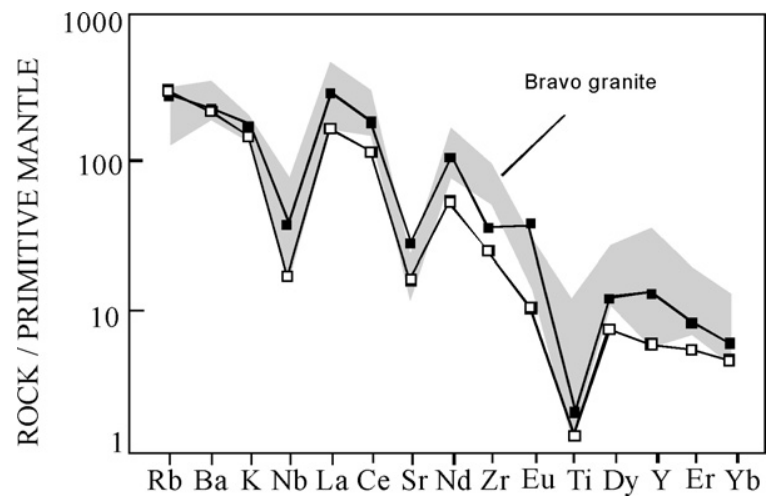

Fig. 19. Spider diagram showing that the patterns of the Bravo Granite and dykes of the Itiúba, Santanápolis and São Felix syenites are very similar and especially, they show exactly the same strong negative anomalies ( $\mathrm{Nb}, \mathrm{Sr}$, $\mathrm{Ti}$, and partly $\mathrm{Eu}$ ). 


\section{Table 4}

Summary of SHRIMP U-Pb zircon results for the Bravo granulite (AM-05A) and the Bravo Granite (AM-12A)

\begin{tabular}{|c|c|c|c|c|c|c|c|c|c|c|c|c|c|c|c|c|c|c|}
\hline \multirow[t]{2}{*}{ Grain. spot } & \multirow[t]{2}{*}{$\mathrm{U}(\mathrm{ppm})$} & \multirow[t]{2}{*}{ Th (ppm) } & \multirow[t]{2}{*}{$\mathrm{Th} / \mathrm{U}$} & \multirow[t]{2}{*}{$\mathrm{Pb}^{*}(\mathrm{ppm})$} & \multirow[t]{2}{*}{${ }^{204} \mathrm{~Pb} /{ }^{206} \mathrm{~Pb}$} & \multirow[t]{2}{*}{$\mathrm{f}_{206} \%$} & \multicolumn{6}{|c|}{ Radiogenic Ratios } & \multirow[b]{2}{*}{$\rho$} & \multicolumn{5}{|l|}{ Age (Ma) } \\
\hline & & & & & & & ${ }^{206} \mathrm{~Pb} /{ }^{238} \mathrm{U}$ & \pm & ${ }^{207} \mathrm{~Pb} /{ }^{235} \mathrm{U}$ & & ${ }^{207} \mathrm{~Pb} /{ }^{206} \mathrm{~Pb}$ & \pm & & ${ }^{206} \mathrm{~Pb} /{ }^{238} \mathrm{U}$ & & ${ }^{207} \mathrm{~Pb} /{ }^{206} \mathrm{~Pb}$ & \pm & $\%$ \\
\hline \multicolumn{19}{|c|}{ Bravo Granulite AM-05A } \\
\hline 1,1 & 276 & 263 & 0.95 & 90.4 & -0.000002 & $\mathrm{O}_{9} \mathrm{O}$ & 0.3813 & 0.0027 & 6.709 & 0.054 & 0.1276 & 0.0005 & 0.881 & 2082 & 13 & 2066 & 7 & -1 \\
\hline 2,1 & 695 & 204 & 0.29 & 168.7 & 0.000193 & 0.29 & 0.2815 & 0.0021 & 4.678 & 0.29 & 0.1205 & 0.0005 & 0.887 & 1599 & 10 & 1964 & 7 & 19 \\
\hline 3,1 & 193 & 153 & 0.79 & 63.6 & 0.000028 & 0.04 & 0.3829 & 0.0043 & 6.694 & 0.081 & 0.1268 & 0.0006 & 0.921 & 2090 & 20 & 2054 & 8 & -2 \\
\hline 4,1 & 191 & 128 & 0.67 & 63.1 & 0.000038 & 0.06 & 0.3847 & 0.0 & 6.719 & 0.064 & 0.1267 & 0.0007 & 0.829 & 2098 & 14 & 2052 & 9 & -2 \\
\hline 5,1 & 229 & 198 & 0.86 & 74.8 & 0.000032 & 0.05 & 0.3804 & 0.0028 & 6.676 & 0.060 & 0.1273 & 0.0006 & 0.824 & 2078 & 13 & 2061 & 9 & -1 \\
\hline 6,1 & 260 & 258 & 0.99 & 84.4 & 0.00000 & 0.00 & 0.3777 & 0.0027 & 6.638 & 0.055 & 0.1275 & 0.0005 & 0.873 & 2065 & 13 & 2063 & 7 & 0 \\
\hline 7,1 & 233 & 229 & 0.98 & 75.9 & 0.000015 & 0.02 & 0.3784 & 0.0028 & 6.662 & 0.062 & 0.1277 & 0.0007 & 0.794 & 2069 & 13 & 2066 & 10 & 0 \\
\hline 8,1 & 201 & 161 & 0.80 & 66.2 & -0.000002 & 0.00 & 0.3824 & 0.0029 & 6.763 & 0.060 & 0.1283 & 0.0006 & 0.860 & 2087 & 14 & 2075 & 8 & -1 \\
\hline 9,1 & 226 & 251 & 1.11 & 73.8 & 0.000342 & 0.51 & 0.3787 & 0.0029 & 6.683 & 0.071 & 0.1280 & 0.0010 & 0.714 & 2070 & 13 & 2071 & 13 & 0 \\
\hline 10,1 & 190 & 129 & 0.68 & 61.4 & 0.000032 & 0.05 & 0.3764 & 0.0029 & 6.653 & 0.8332 & 0.1282 & 0.0007 & 0.833 & 2059 & 14 & 2074 & 9 & 1 \\
\hline 11,1 & 74 & 238 & 3.21 & 250.00 & 0.000050 & 0.07 & 0.3925 & 0.0041 & 6.812 & 0.096 & 0.1259 & 0.0012 & 0.739 & 2134 & 19 & 2041 & 17 & -5 \\
\hline 12,1 & 380 & 90 & 0.24 & 121.1 & 0.001961 & 2.77 & 0.3611 & 0.0036 & 8.134 & 0.098 & 0.1634 & 0.0012 & 0.813 & 1987 & 17 & 2491 & 12 & 20 \\
\hline 13,1 & 391 & 200 & 0.51 & 139.2 & 0.000167 & 0.24 & 0.4128 & 0.0028 & 8.764 & 0.075 & 0.1540 & 0.0008 & 0.780 & 2228 & 13 & 2391 & 9 & 7 \\
\hline \multicolumn{19}{|c|}{ Bravo Granite AM-12A } \\
\hline 1,1 & 92 & 76 & 0.83 & 31.2 & 0.000074 & 0.11 & 0.3943 & 0.0039 & 6.881 & 0.085 & 0.1266 & 0.0009 & 0.805 & 2143 & 18 & 2051 & 13 & -4 \\
\hline 2,1 & 467 & 111 & 0.24 & 154.7 & 0.000044 & 0.07 & 0.3852 & 0.0025 & 6.743 & 0.049 & 0.1270 & 0.0004 & 0.897 & 2100 & 12 & 2056 & 6 & -2 \\
\hline 3,1 & 91 & 108 & 1.19 & 30.5 & 0.000017 & 0.03 & 0.3892 & 0.0039 & 6.880 & 0.084 & 0.1282 & 0.0009 & 0.817 & 2119 & 18 & 2073 & 12 & -2 \\
\hline 4,1 & 381 & 188 & 0.49 & 122.5 & 0.000191 & 0.29 & 0.3728 & 0.0027 & 6.561 & 0.056 & 0.1277 & 0.0006 & 0.837 & 2042 & 13 & 2066 & 8 & 1 \\
\hline 4,2 & 167 & 129 & 0.77 & 55.4 & 0.000036 & 0.05 & 0.3854 & 0.0056 & 6.765 & 0.104 & 0.1273 & 0.0007 & 0.942 & 2102 & 26 & 2061 & 9 & -2 \\
\hline 5,2 & 54 & 69 & 1.27 & 18.2 & 0.000092 & 0.14 & 0.3919 & 0.0047 & 6.769 & 0.109 & 0.1253 & 0.0013 & 0.753 & 2132 & 22 & 2033 & 19 & -5 \\
\hline 6,1 & 196 & 101 & 0.51 & 64.4 & 0.000029 & 0.04 & 0.3829 & 0.0 & 6.738 & 0.062 & 0.1276 & 0.0006 & 0.846 & 2090 & 14 & 2066 & 9 & -1 \\
\hline 7,1 & 47 & 50 & 1.06 & 15.7 & - & $<0.01$ & 0.3883 & 0.0078 & 6.895 & 0.164 & 0.1288 & 0.16 & 0.845 & 2115 & 36 & 2082 & 22 & -2 \\
\hline 8,1 & 114 & 60 & 0.52 & 38.5 & 0.000045 & 0.07 & 0.3913 & 0.0036 & 6.887 & 0.077 & 0.1277 & 0.0008 & 0.821 & 2129 & 17 & 2066 & 11 & -3 \\
\hline 9,1 & 48 & 49 & 1.03 & 15.7 & - & $<0.01$ & 0.3839 & 0.0049 & 6.807 & 0.108 & 0.1286 & 0.0012 & 0.798 & 2094 & 23 & 2079 & 17 & -1 \\
\hline 10,1 & 51 & 48 & 0.95 & 16.3 & 0.000079 & 0.12 & 0.3716 & 0.0045 & 6.543 & 0.104 & 0.1277 & 0.0013 & 0.758 & 2037 & 21 & 2066 & 18 & 1 \\
\hline 11,1 & 106 & 99 & 0.94 & 34.4 & 0.000093 & 0.14 & 0.3774 & 0.0063 & 6.510 & 0.119 & 0.1251 & 0.0010 & 0.909 & 2064 & 29 & 2030 & 13 & -2 \\
\hline
\end{tabular}

Notes: (1) Uncertainties given at the one $\sigma$ level. (2) $f_{206} \%$ denotes the percentage of ${ }^{206} \mathrm{~Pb}$ that is common $\mathrm{Pb}$. (3) Correction for common $\mathrm{Pb}$ made using the measured ${ }^{204} \mathrm{~Pb} /{ }^{206} \mathrm{~Pb}$ ratio. (4) For \% Disc., $0 \%$ denotes a concordant analysis. 

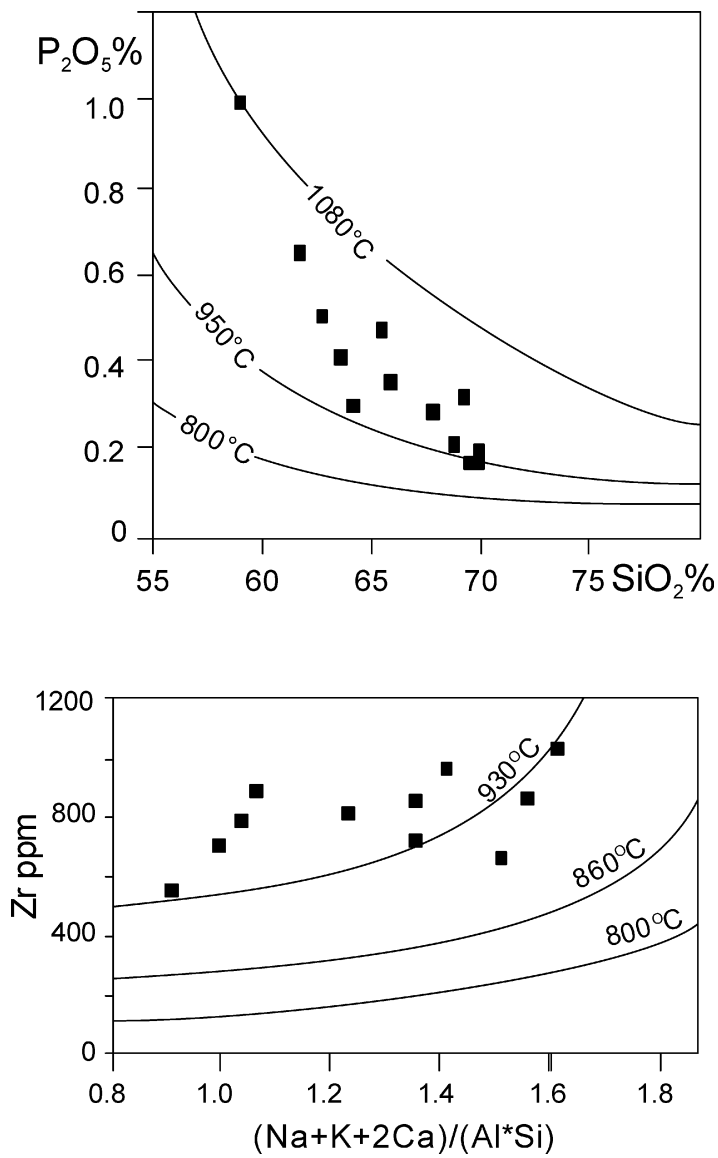

Fig. 20. Diagram suggesting that Bravo granite was crystallized at temperatures between 900 and $1000^{\circ} \mathrm{C}$ (Green and Watson, 1982; Watson and Harrison, 1983).

\subsection{Zircon dating of the Tanquinho granulite $\mathrm{LH}-182$}

The Tanquinho granulite LH-182 contains two types of zircon grains. One is euhedral, elongated, and belongs to the S18-22-2325 high-temperature types of Pupin (1980) with fine magmatic

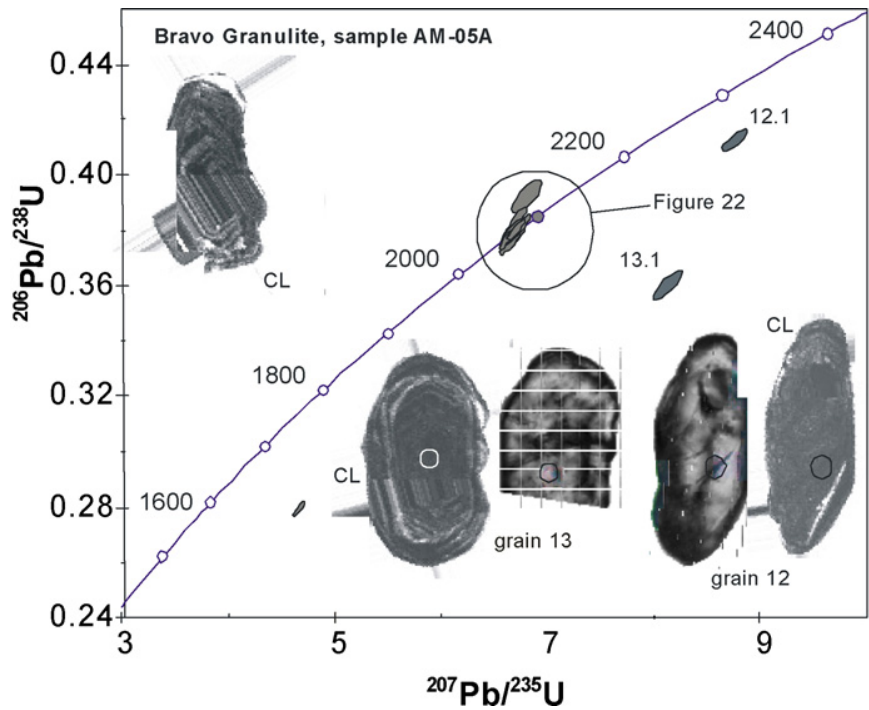

Fig. 21. U-Pb zircon concordia diagram for the Bravo granulite AM-05A, with the probably inherited metamict and corroded zircon grains. Circles indicate the SHRIMP spots.

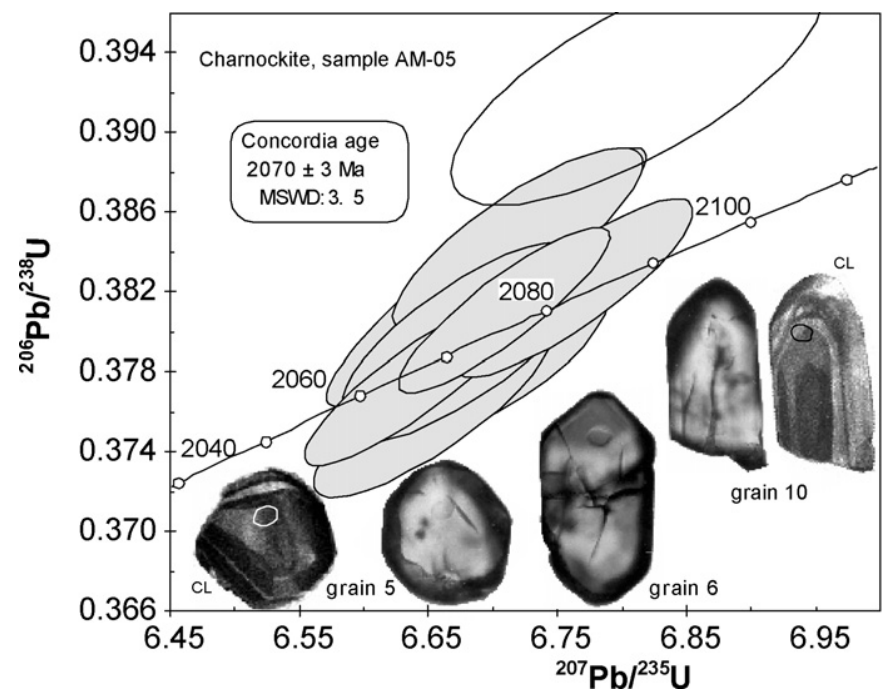

Fig. 22. Concordia diagram for the clear euhedral zircon grains. Cathodoluminescence $(\mathrm{CL})$ and transmitted-light images of analysed and of some other zircons. Circles indicate the SHRIMP spots.

zoning. The second type is composed of rounded zircons also of high temperature types (S22-23), of possible metamorphic affinity, similar to some of these found in the Bravo charnockite (Fig. 23) ${ }^{207} \mathrm{~Pb} /{ }^{206} \mathrm{~Pb}$ TIMS evaporation ages were determined on the two types of zircon grains and are (1) of $2098 \pm 1$ Ma to $2101 \pm 5$ Ma for the two magmatic grains and (2) of $2094 \pm 3$ Ma for the rounded zircon, the average of all data is $2096 \pm 3 \mathrm{Ma}$ (Table 5, Fig. 23). Two interpretations are possible: (i) both types of zircons have a magmatic origin and were formed at $2096 \pm 3 \mathrm{Ma}$ and the high-grade metamorphism is younger or (ii) the emplacement of the granitic magmas and the granulite facies metamorphism occurred together during a very short time interval at $2096 \pm 3 \mathrm{Ma}$.

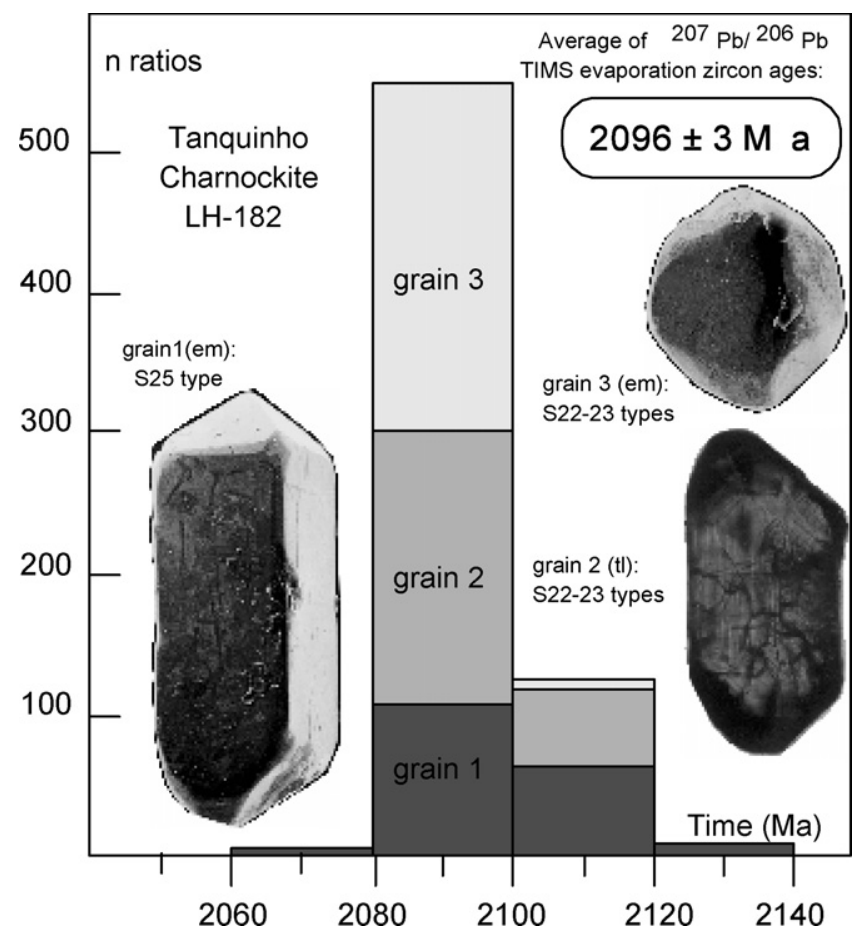

Fig. 23. Histogram of TIMS evaporation zircon ages for Tanquinho granulite LH-182 Electronic microprobe (em) and transmitted-light (tl) images. 
Table 5

Summary of TIMS evaporation ages for the Tanquinho granulite (LH-182)

\begin{tabular}{|c|c|c|c|c|c|c|c|}
\hline$n$ ratios & Step (A) & ${ }^{206} \mathrm{~Pb} /{ }^{204} \mathrm{~Pb}$ & ${ }^{207} \mathrm{~Pb} /{ }^{206} \mathrm{~Pb}$ & Error 2 sig. $\mathrm{m}$ & ${ }^{207} \mathrm{~Pb} /{ }^{206} \mathrm{~Pb}$ corrected & ${ }^{207} \mathrm{~Pb} /{ }^{206} \mathrm{~Pb}$ age & error 2 sig. \\
\hline \multicolumn{8}{|c|}{ Grain 1 (elongated, S24-25 type) } \\
\hline 100 & 2.6 & 41613 & 0.1302 & 0.7 & 0.1300 & 2098 & 2 \\
\hline 80 & 2.8 & 278762 & 0.1303 & 2 & 0.1302 & 2101 & 5 \\
\hline \multicolumn{8}{|c|}{ Grain 2 (elongated, S25 type) } \\
\hline 60 & 2.6 & 48605 & 0.1300 & 3 & 0.1299 & 2097 & 8 \\
\hline 100 & 2.8 & 99174 & 0.1299 & 1 & 0.1298 & 2095 & 3 \\
\hline 100 & 3.2 & 260826 & 0.1300 & 0.2 & 0.1300 & 2098 & 1 \\
\hline \multicolumn{8}{|c|}{ Grain 3(round, S22-23 type) } \\
\hline 160 & 2.8 & 31945 & 0.1289 & 1 & 0.1288 & 2082 & 3 \\
\hline \multirow[t]{2}{*}{120} & 3.2 & 308084 & 0.1297 & 1 & 0.1297 & 2094 & 3 \\
\hline & & & & & Average of the 3 grains & 2096 & 3 \\
\hline
\end{tabular}

\subsection{Nd isotopes of the granulites}

The Bravo granulites have $\varepsilon_{\mathrm{Nd}}$ values at $2.07 \mathrm{Ga}$ which range between -2.7 and -6.2 and depleted mantle model ages $\left(T_{\mathrm{DM}}\right)$ between 2.65 and $2.73 \mathrm{Ga}$ (Table 6). These data, with the occurrence of inherited zircons up to $2.5 \mathrm{Ga}$, also evidence a Neoarchaean component in the granulites. Taking into account the high $\mathrm{A} / \mathrm{CNK}$ of some granulites, they could be formed by partial melting of older TTG. On an other hand, some juvenile magmas could have been formed $c a .2 .1 \mathrm{Ga}$ as suggested by the Tanquinho granulite Nd signature. It exhibits a $T_{\mathrm{DM}}$ age of $2.54 \mathrm{Ga}$ with an $\varepsilon_{\mathrm{Nd}}$ of -1.8 at $2.1 \mathrm{Ga}$ suggesting mixing processes between a Palaeoproterozoic juvenile crust and an inherited Archaean component.

\subsection{Zircon dating of the Bravo granite AM-12A}

Zircon grains from sample AM-12A are all euhedral, elongated with fine magmatic zoning and of high temperature types (S1824) without any visible inherited cores (Fig. 24). U-Pb SHRIMP results are concordant (Table 4, Fig. 24) and the 12 analyses define an intercept at $2062 \pm 9 \mathrm{Ma}(\mathrm{MSWD}=1.3)$ and a mean ${ }^{207} \mathrm{~Pb} /{ }^{206} \mathrm{~Pb}$ age at $2060 \pm 6 \mathrm{Ma}(\mathrm{MSWD}=1.2)$ which is interpreted as that of the magmatic event. Even it is similar to the age found for the Bravo charnockite $(2064 \pm 6 \mathrm{Ma})$, this result suggests that the Bravo granulitic basement was uplifted at $2060 \pm 6$ Ma during the emplacement of the granite, in the amphibolite facies metamorphism. This also indicates that the high-grade metamorphism was developed between $2060 \pm 6$ and $2064 \pm 6$ Ma in the Bravo region.

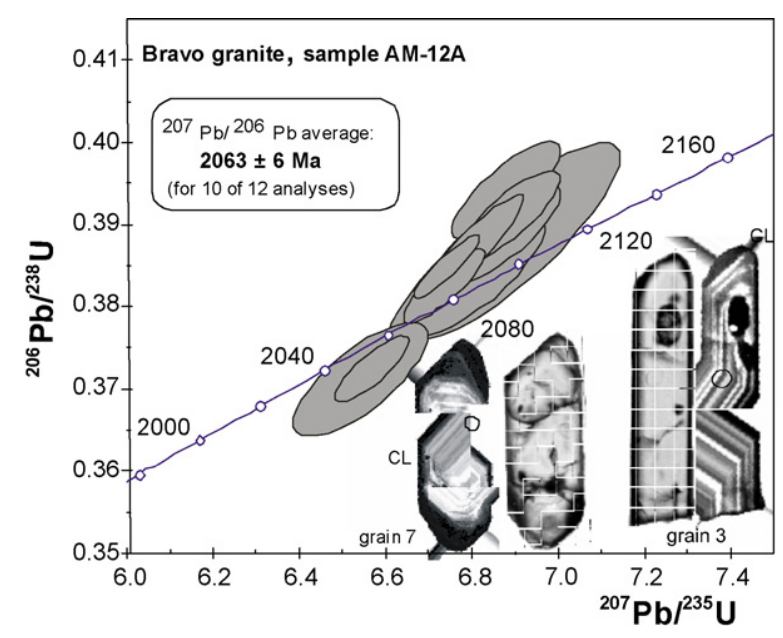

Fig. 24. U-Pb zircon concordia diagram for the Bravo granite AM-12A, Cathodoluminescence $(\mathrm{CL})$ and transmitted-light images of analysed zircons. Circles indicate the SHRIMP spots.

\subsection{Nd isotopes of the Bravo Granite}

The 2.06 Ga Bravo granites have slight more negative $\varepsilon_{\mathrm{Nd}}(-6.3$ to -7.7 ) and higher $\mathrm{T}_{\mathrm{DM}}(2.75$ to $2.90 \mathrm{Ga})$ than the surrounding granulites. These results indicate that the Bravo granite is derived from Mesoarchaean material or alternatively contain a large amount of Mesoarchaean component. Furthermore, in the $\varepsilon_{\mathrm{Nd}}$ vs. time dia-

Table 6

Sm-Nd isotope data for the Bravo granulites, Bravo granites and Tanquinho granulite

\begin{tabular}{|c|c|c|c|c|c|c|c|c|c|}
\hline & & $\mathrm{Sm}(\mathrm{ppm})$ & $\mathrm{Nd}(\mathrm{ppm})$ & ${ }^{147} \mathrm{Sm} /{ }^{144} \mathrm{Nd}$ & ${ }^{143} \mathrm{Nd} /{ }^{144} \mathrm{Nd}$ & Error $\left(\times 10^{-6}\right) \pm$ & $\varepsilon_{\mathrm{Nd}}$ at $0 \mathrm{Ga}$ & $T_{\mathrm{DM}}, \varepsilon_{\mathrm{Nd} 0}=+10$ in $\mathrm{Ga}$ & $\varepsilon_{\mathrm{Nd}}$ at zircon age \\
\hline Bravo & & & & & & & & & $(2.07 \mathrm{Ga})$ \\
\hline \multirow[t]{2}{*}{ Granulite } & AM-01A & 22.9 & 165 & 0.0837 & 0.510807 & 3 & -36 & 2.73 & -5.9 \\
\hline & AM-01A dup & 23.0 & 168 & 0.0827 & 0.510781 & 3 & -36 & 2.74 & -6.2 \\
\hline \multirow[t]{2}{*}{ Granulite } & AM-05A & 21.6 & 166 & 0.0789 & 0.510729 & 4 & -37 & 2.72 & -6.2 \\
\hline & AM-05A dup & 21.0 & 165 & 0.0771 & 0.510711 & 3 & -38 & 2.71 & -6.0 \\
\hline \multirow[t]{2}{*}{ Granulite } & AM-15B & 3.08 & 16.5 & 0.1124 & 0.511353 & 3 & -25 & 2.69 & -2.8 \\
\hline & AM-15B dup & 3.15 & 17.1 & 0.1115 & 0.511347 & 3 & -25 & 2.67 & -2.7 \\
\hline Granulite & AM-15A & 1.71 & 12.4 & 0.0832 & 0.510868 & 3 & -35 & 2.65 & -4.6 \\
\hline \multicolumn{9}{|l|}{ Bravo } & $(2.06 \mathrm{Ga})$ \\
\hline \multirow[t]{2}{*}{ Granite } & EF-18C & 2.73 & 17.4 & 0.0950 & 0.510875 & 3 & -34 & 2.90 & -7.7 \\
\hline & EF-18C dup & 3.37 & 21.7 & 0.0939 & 0.510861 & 4 & -35 & 2.89 & -7.7 \\
\hline Granite & AM-01B & 22.4 & 159 & 0.0848 & 0.510808 & 4 & -36 & 2.75 & -6.3 \\
\hline Granite & AM-12A & 25.0 & 151 & 0.0998 & 0.511002 & 3 & -32 & 2.86 & -6.5 \\
\hline Tanquinho & & & & & & & & & $(2.10 \mathrm{Ga})$ \\
\hline Granulite & LH-182 & 2.42 & 15.90 & 0.0918 & 0.511108 & 5 & -30 & 2.54 & -1.8 \\
\hline
\end{tabular}

dup: duplicate. 


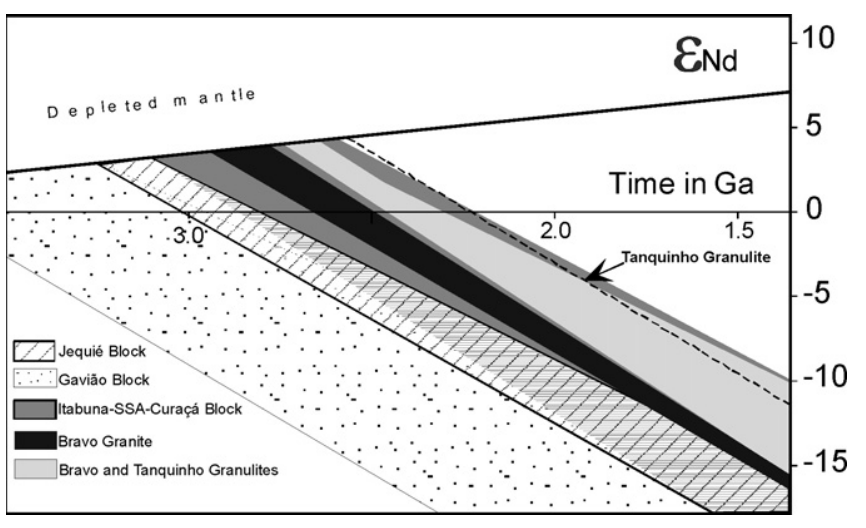

Fig. 25. Nd isotopic vs. time evolution diagram for the Bravo-Tanquinho samples compared to other rock-types of the São Francisco craton.

gram (Fig. 25), the Bravo charnockitic granulites and the granite defined two separate fields which would suggest various sources for the two magmatic suites, but that could result of the restricted number of samples studied and to be not really significant. In Fig. 25, we also reported the Nd isotopic evolution of the Gavião Archaean block (data after Marinho, 1991; Martin et al., 1997; Santos Pinto et al., 1998; Peucat et al., 2002) and that of the Jequié granulites (after Wilson, 1987; Barbosa et al., 2004). The Archaean Gavião samples have the most negative $\varepsilon_{\mathrm{Nd}}$ values ca. $2.1 \mathrm{Ga}$ and do not constitute, alone, a potential source for the Bravo units. The Jequié granulites are also more negative even they plot between Gavião samples and Bravo granites. The crustal protoliths involved in the granulite of the Bravo area are younger than these forming Gavião and Jequié old Archaean basements.

\section{Discussion and conclusion}

The granulites in the Bravo-Tanquinho region are peraluminous, medium-K calc-alkaline TTG-like rocks. Chondrite-normalised REE patterns allow to distinguish two groups: (i) the first one has strongly fractionated patterns with high LREE contents $\left(\operatorname{La}_{N}>100\right)$, very low HREE contents $\left(\mathrm{Yb}_{\mathrm{N}}<3\right)$, without significant Eu anomalies, and with a slightly concave shape at the HREE end and (ii) the second one is slightly poorer in both $\operatorname{LREE}\left(50<\mathrm{La}_{\mathrm{N}}<120\right)$ and HREE $\left(\mathrm{Yb}_{\mathrm{N}}<2\right)$ but usually with significant positive Eu anomaly.

Consistent $\mathrm{Nd}$ model ages of the Bravo granulites indicate a Neoarchaean crustal component which is in the range of the ca. 2.7 Ga ages found in other granulites from the Caraíba Complex (Oliveira et al., 2004). Furthermore, the occurrence of Neoarchaean magmatism in the granulite of the Caraíba Complex was shown by the SHRIMP zircon age at ca. 2.66 Ga for the Capelinha enderbites (Silva et al., 2002, Fig. 2). This would favoured the hypothesis of recycling of a $\sim 2.7 \mathrm{Ga}$ basement at about $2.06 \mathrm{Ga}$. It would account for the high $\mathrm{A} / \mathrm{CNK}$ of some samples and the low $\varepsilon_{\mathrm{Nd}}$.

The zircon age of the Tanquinho granulite is significantly different with magmatic zircons ca. 2.1 Ga. The $\varepsilon_{\mathrm{Nd}}$ is slightly less negative than for the Bravo granulites, and the model age of 2.5 Ga younger. This rock was probably formed at ca. 2.1 Ga from TTGtype magma which incorporated Archaean host rocks. The age of magmatic zircon is $2096 \pm 3$ Ma while the rounded zircon was possibly formed under granulite facies conditions close to this time. If the metamorphic age is truly synchronous with that of the Tanquinho magmatism, taking into account the 2.06-2.07 Ga age of the Bravo granulite, this suggests that the peak metamorphism lasted for around 30-40 Ma in this part of the Caraíba Complex. A metamorphic stage ca. $2.1 \mathrm{Ga}$ seems confirmed by new zircon SHRIMP ages about granulites in the southern part of the Itabuna-Salvador-
Curaçá block which indicate a high grade event at ca. 2.1 Ga (Pinho et al., submitted for publication). On the other hand, Barbosa et al. (2005) used the ages and geology of late-tectonic syenites and post-tectonic granites in the ISCO to estimate duration of about 30 Ma for the granulite facies metamorphism. For the whole Palaeoproterozoic metamorphism from progressive to retrogressive phase the duration was estimated at about $50 \mathrm{Ma}$.

In contrast to the granulites the Bravo granite is mostly metaluminous; in addition they are $\mathrm{K}_{2} \mathrm{O}$-rich (4.03-5.95\%), which confer to the rocks a high-K to shoshonitic affinities. The Nb vs. Y diagram (Fig. 14) reveals its "Within Plate Granite" affinity, and the $\mathrm{Nb}-\mathrm{Ce}-\mathrm{Y}$ diagram shows that it belongs to the A-2 type. Fractional crystallization was responsible for the differentiation of the Bravo granite.

As previously mentioned the São Francisco Craton can be subdivided into four major Archaean geological units, which were amalgamated during a Palaeoproterozoic complex collision responsible for the formation of the ISCO. The high-grade metamorphism which resulted from crustal thickening that accompanied the collision reached the granulite facies with a minimum pressure of 5-7 kbar and a temperature of $850-870{ }^{\circ} \mathrm{C}$ in the centre of the orogen, and greenschist facies at its margins (Barbosa and Sabaté, 2002, 2004; Barbosa et al., 2005). Three major stages of ductile deformation were contemporaneous with high-grade metamorphism at $c a$. 2.0-2.1 Ga. At the end of the deformation the uplifted granulites were subject to shearing and faulting under amphibolite facies conditions. Late-tectonic syenites and post-tectonic granites (including the Bravo intrusion) were emplaced along these discontinuities. The intrusive rocks have very similar ages close to that of the metamorphic peak.

Not only the age, but also the geochemistry of the Bravo granite is very similar to that of the late dykes which cut the syenite intrusions. The large syenite massifs are cumulates, or were formed from dense crystal suspensions. The residual liquids represent minor volumes compared to the very large size of the syenite masses, but in places such as the Bravo region could have escaped through faults and shear zones to form intrusions during the final stages of evolution of the ISCO. It must also be mentioned that the large syenitic massifs were interpreted as being mostly cumulative facies (Plá Cid et al., 2006; Rios et al., 2007), the magmatic liquid having been removed. Until now the big volumes of this liquid remained unknown. The Bravo granite could be one part of these liquids.

\section{Analytical procedures}

The samples were analysed for major and trace elements in the GEOSOL-Geologia e Sondagem Ltda Laboratories using X-ray fluorescence, ICP-MS and atomic absorption spectrometry. With XRF it was possible to conduct quantitative sample analysis for most major and trace elements, while ICP-MS is adequate specially for the determination of small amount of rare earth elements with concentration around 10 times chondrite. Atomic absorption spectrometry was used to determine elements such as $\mathrm{Na}_{2} \mathrm{O}$ and $\mathrm{K}_{2} \mathrm{O}$. U-Pb zircon analyses were made using SHRIMP I (ANU Canberra), each analysis consisting of six scans through the mass range. The $\mathrm{Pb} / \mathrm{U}$ ratios have been normalised relative to a value of 0.1859 for the ${ }^{206} \mathrm{~Pb} /{ }^{238} \mathrm{U}$ ratio of the AS3 reference zircons, equivalent to an age of 1099 Ma (Paces and Miller, 1993). Uncertainties given for individual analyses (ratios and ages) are at the $1 \sigma$ level, however the uncertainties in calculated weighted mean ages are reported at $95 \%$ confidence limits. Weighted mean ${ }^{207} \mathrm{~Pb} /{ }^{206} \mathrm{~Pb}$ ages were carried out using ISOPLOT/EX (Ludwig, 1999). ${ }^{207} \mathrm{~Pb} /{ }^{206} \mathrm{~Pb}$ TIMS zircon evaporation (Kober, 1986) and Nd isotopes were performed on a Finnigan Mat 262 mass spectrometer at Géosciences RennesCNRS, following classical procedures (Peucat et al., 1999). Replicate 
analyses for $\mathrm{Pb}$ and $\mathrm{Nd}$ standards were obtained during this work. NBS 983: ${ }^{206} \mathrm{~Pb} /{ }^{204} \mathrm{~Pb}=2759 \pm 1,{ }^{207} \mathrm{~Pb} /{ }^{206} \mathrm{~Pb}=0.071238 \pm 7$ and $\varepsilon_{\mathrm{Nd}}$ standard: ${ }^{143} \mathrm{Nd} /{ }^{144} \mathrm{Nd}=0.512106 \pm 4$. Nd model ages were calculated using $\varepsilon_{\mathrm{Nd}}$ values of +10 for the present day depleted mantle and ${ }^{147} \mathrm{Sm} /{ }^{144} \mathrm{Nd}=0.2137$, following a radiogenic linear growth for the mantle starting at $4.54 \mathrm{Ga}$. For ${ }^{207} \mathrm{~Pb} /{ }^{206} \mathrm{~Pb}$ zircon evaporation ages, correction for common lead used the composition calculated from the two-stage model of Stacey and Kramers (1975). Errors on ${ }^{207} \mathrm{~Pb} /{ }^{206} \mathrm{~Pb}$ ages are the weighted average at the $2 \sigma$ level of ages and errors obtained on independent runs of 20 ratios, using the Isoplot programme of Ludwig (1999). Each grain is analysed at different temperature steps (low, high and very high) corresponding to currents of $2.6,3.0$ and $3.3 \mathrm{~A}$ (approximatively to $1480^{\circ}, 1540^{\circ}$ and $1610^{\circ} \pm 10^{\circ} \mathrm{C}$ ). All ages are calculated using the decay constants and isotopes abundances listed by Steiger and Jäger (1977).

\section{Acknowledgements}

This research was funded by CNPq, CAPES-COFECUB collaborative project France-Brazil $\left(\mathrm{n}^{\circ}\right.$ 381/02) and by CBPM-Companhia Baiana de Pesquisa Mineral. We thank Umberto G. Cordani, and an anonymous referee for their constructive discussions and detailed reviews that improved considerably the manuscript and Ian McReath is thanked for his comments, and for preparing the English version.

\section{References}

Aillon, M.P., 1992. Caracterização petroquimica e do metamorfismo das rochas granulíticas da região de Cachoeira-São Felix-Cruz das Almas, Bahia. M.Sc. Thesis. unpublished. University of Bahia, Brazil, 165 pp.

Alibert, C., Barbosa, J.S.F., 1992. Ages U-Pb déterminés à la "SHRIMP” sur des zircons du Complexe de Jequié, Craton du São Francisco, Bahia, Brésil. In: 14 Réunion Science de la Terre, Toulouse, Soc. Géol. France, p. 4.

Almeida, F.F.M. de, 1977. O Craton do São Francisco. Rev. Bras. Geoci. 7, 349-364.

Barbosa, J.S.F., 1986. Constitution lithologique et métamorphique de la région granulitique du Sud de Bahia, Brésil. Unpublished Thesis. Université Pierre et Marie Curie, Paris, France, 401 pp.

Barbosa, J.S.F., 1990. The granulites of the Jequié Complex and Atlantic Mobile Belt, Southern Bahia, Brazil-an expression of Archaean-Proterozoic plate convergence. In: Vielzeuf, D., Vidal, Ph. (Eds.), Granulites and Crustal Evolution. Proceedings of ARW. Springer-Verlag, Clermont Ferrand (France), pp. 195-221.

Barbosa, J.S.F., Dominguez, J.M.L., 1996. Texto Explicativo para o Mapa Geológico da Bahia ao Milionésimo. SICM/SGM, Salvador (Edição Especial), 400p.

Barbosa, J.S.F., Fonteilles, M., 1991. Síntese sobre o metamorfismo da região granulítica do sul da Bahia, Brasil. Rev. Bras. Geoci. 21 (4), 328-341.

Barbosa, J.S.F., Sabaté, P., 2002. Geological features and the Paleoproterozoic collision of four Archaean crustal segments of the São Francisco Craton, Bahia, Brazil. A synthesis. Anais Acad. Bras. Ciê. 74 (2), 343-359.

Barbosa, J.S.F., Sabaté, P., 2004. Archaean and Palaeoproterozoic crust of the São Francisco Cráton, Bahia, Brazil: geodynamic features. Precambrian Res. 133, 1-27.

Barbosa, J.S.F., Corrêa-Gomes, L. C., Leite, C. M. M., Sabaté, P., 2005. O metamorfismo e o plutonismo paleoproterozoico do Orógeno Itabuna-Salvador-Curaçá, Craton do São Francisco, Bahia. Short Papers. III Simp. Cráton do São Francisco. Anais, $59-62$.

Barbosa, J.S.F., Martin, H., Peucat, J.J., 2004. Archaean/Palaeoproterozoic Crustal Domic Evolution of the Lage, Mutuipe, Brejões and Santa Ines Région. Jequié Block, Bahia, Brazil. Precambrian Res. 135, 105-131.

Barker, F., 1987. Trondhjemites: definition, environment and hypothesis of origin. In: Barker, F. (Ed.), Trondhjemites, Dacites and Related Rocks. Elsevier, Amsterdam, pp. 1-12.

Brito Neves, B.B., Cordani, U.G., Torquato, J.R.F., 1980. Evolução geocronológica do Precambriano do Estado da Bahia. In: Inda, H., Barbosa, J.F.S. (Eds.). Geologia e Recursos Minerais do Estado da Bahia. Secretaria das Minas do Estado da Bahia. Textos Básicos, 1:1-101.

Caby, R., Bertrand, J.M., Black, R., 1981. Pan-African ocean closure and continental collision in the Hoggar-Iforas segment, central Sahara. In: Kroner, A. (Ed.) Precambrian Plate Tectonics. Elsevier, pp. 407-434.

Clemens, J.D., Holloway, J.R., 1996. Origin of an A-type granite: experimental constraints. Am. Miner. 71, 317-324.

Collins, W.J., Beams, S.D., 1982. Nature and origin of A-type granites with particular reference to south-eastern Australia. Contrib. Mineral. Petr. 80, 189-200.

Conceição, H., 1990. Petrologie du Massif Syenitique d'Itiuba: contribuition à l'etude mineralogique des roches alcalines dans l'Etat de Bahia (Brésil). PhD Thesis. Centre D’Orsey, Université Paris-Sud, 395 pp.
Conceição, R.V., 1994. Petrologia do sienitos potássicos do Maciço de Santanápolis e alguns aspectos do seu embasamento granulítico. Dissertação de Mestrado. UFBA. 275 pp.

Conceição, R.V., 1998. Petrologia dos sienitos potássicos do Maciço de Santanápolis e alguns aspectos do seu embasamento granulítico. In: Conceição, H, Cruz, M.J.M. (Eds.), Sienitos alcalino-potássicos e ultrapotássicos Paleoproterozoicos do Estado da Bahia. Publicação Especial no 4, Sociedade. Brasileira de Geologia., Núcleo Bahia-Sergipe, 41-82.

Cordani, U.G., Sato, K., Marinho, M.M., 1985. The geologic evolution of the ancient granite greenstone terrane of central-southern Bahia, Brazil. Precambrian Res. 27, 187-213

Creaser, R.A., Price, R.R., Wormald, R.J., 1991. A-type granites revised. Assessement of a residual-source model. Geology 19, 163-166.

Cunha, J.C., Bastos Leal, L.R., Fróes, R.J.B., Teixeira, W., Macambira, M.J.B., 1996. Idade dos Greenstone Belts e dos terrenos TTGs associados da Região do Cráton do São Francisco (Bahia, Brasil). In: Congresso. Brasileiro de Geologia, 29. Salvador, 1996. Anais, Salvador, 1, 62-65.

Defant, M.J., Drummond, M.S., 1990. Derivation of some modern arc magmas by melting of young subducted lithosphere. Nature 347, 662-665.

Eby, G.N., 1992. Chemical subdivision of the A-type granitoids: petrogenetic and tectonic implications. Geology 20, 641-644.

Green, T.H., Watson, E.B., 1982. Crystallization of apatite in natural magmas under high-pressure, hydrous conditions, with particular reference to 'orogenic' rock series. Contrib. Mineral. Petr. 79, 96-105.

Irvine, T.N., Baragar, W.R.A., 1971. A guide to the chemical classification of the common volcanic rocks. Can. J. Earth Sci. 8, 523-548.

Jardim de Sá, E.F.J., Souza, Z.S., Fonseca, V.P., Legrand, J.M., 1984. Relações entre "greenstone belts" e terrenos de alto grau: o caso da Faixa Rio Capim, NE da Bahia. In: Proceedings of the XXXIII Congresso Brasileiro de Geologia, Rio de Janeiro, pp. 2615-2629.

Kober, B., 1986. Whole-grain evaporation for ${ }^{207} \mathrm{~Pb} /{ }^{206} \mathrm{~Pb}$ age investigations on single zircons using a double-filament thermal ion source. Contrib. Mineral. Petr. 93, 482-490.

Kretz, R., 1983. Symbolls for rock-forming minerals. Am. Miner. 68, 277-279.

Kuno, H., 1968. Differentiation of basalt magmas. In: Hess, H.H., Poldervaart, A. (Eds.), The Poldevaart Treatise on Rocks of Basaltic Composition, vol. 2. Ed. Interscience, New York, pp. 623-688.

Lameyre, J., Bowden, P., 1982. Plutonic rock type series: discrimination of various granitoid series and related rocks. J. Volcanol. Geoth. Res. 14, 169-186.

Ledru, P., Cocherie, A., Barbosa, J.S.F., Johan, V., Onstott, T., 1994. Âge du métamorphisme granulitique dans le Craton du São Francisco (Brésil). Implications sur la nature de l'orogène transamazonien. C. R. Acad. Sci. Paris 211, $120-125$.

Ludwig, K.R., 1999. User's manual for Isoplot/Ex, Version 2.10. In: A Geochronological Tool for Microsoft Excel. Berkeley Geochronology Center, USA (Special Publication No. 1a).

Marinho, M.M., 1991. La séquence volcano-sedimentaire de Contendas-Mirante et la bordure occidentale du bloc Jequié (Cráton du São Francisco-Brésil): Un exemple de transition Archéean-Protérozoique. PhD. Université. Blaise Pascal, Clermont Ferrand II, France. 388 pp.

Martin, H., 1986. Effect of steeper Archaean geothermal gradient on geochemistry of subduction-zone magmas. Geology 14, 753-756.

Martin, H., 1987. Petrogenesis of Archaean trondhjemites, tonalites and granodiorites from eastern Finland: major and trace element geochemistry. J. Petrol. 28 (5), 921-953.

Martin, H., Moyen, J.-F., 2002. Secular changes in TTG composition as markers of the progressive cooling of the Earth. Geology 30 (4), 319-322.

Martin, H., Peucat, J.J., Sabaté, P., Cunha, J.C., 1997. Crustal evolution in Early Archaean of South America: example of the Sete Voltas Massif, Bahia state, Brazil. Precambrian Res. 82, 35-62.

Martin, H., Sabaté, P., Peucat, J.J., Cunha, J.C., 1991. Un Segment de Croute Continentale d'Áge Archéean Ancien (3.4 milliards d'années): le Massif de Sete Voltas (BahiaBrésil). C. R. Acad. Sci. Paris 313 (Serie II), 531-538.

Martin, H., Smithies, R.H., Rapp, R., Moyen, J.-F., Champion, D., 2005. An overview of adakite, tonalite-trondhjemite-granodiorite (TTG), and sanukitoid: relationships and some implications for crustal evolution. Lithos 79 (1-2), 1-24.

Mascarenhas, J de F., Alves da Silva, E.F., 1994. Greenstone Belt de Mundo Novo (Ba): Caracterização e Implicações Metalogenéticas no Cráton do São Francisco. CBPM. Final Rapport., 32 pp.

Mello, E.F., Xavier, R.P., McNaughton, N.J., Hagemann, S.G., Fletcher, I., Snee, L., 2006. Age constraints on felsic intrusions, metamorphism and gold mineralisation in the Palaeoproterozoic Rio Itapicuru greenstone belt, NE Bahia State, Brazil. Miner. Deposita 40, 849-866.

Melo, R.C., Pereira, L.H.M., Sampaio, A.R., Loureiro, H.S.C., 1991. Projeto GaviãoSerrinha. Textos Explicativos. Fls. 1:1.000.000. In: DNPM/CPRM. Programa de Levantamentos Geológicos Básicos do Brasil. 578 pp.

Melo, R.C., Loureiro, H.S.C., Pereira, L.H.M., 1995. Programa Levantamentos Geológicos Básicos do Brasil: Serrinha, Folha SC-24-Y-D, Escala 1:250.000. Salvador: MME/CPRM/SUREG-AS, $80 \mathrm{pp}$.

Moraes, A.M.V. de, 1997. Caracterização petrográfica e petroquímica das rochas metamórficas de alto grau da região de Bravo, município de Serra Preta, Bahia. Dissertação de Mestrado. Universidade Federal da Bahia, 98 pp.

Moyen, J.F., Martin, H., Jayananda, M., Auvray, B., 2003. Late Archaean granites: a typology based on the Dharwar Craton (India). Precambrian Res. 127 (1-3), 103-123. 
Nutman, A.P., Cordani, U.G., 1993. SHRIMP U-Pb zircon geochronology of Archaean granitoids from the Contendas-Mirante area of the São Francisco Craton, Bahia, Brazil. Precambrian Res. 63 (3-4), 179-188.

O'Connor, J.T., 1965. A classification of quartz-rich igneous rocks based on feldspar ratios. Washington US Government Printing Office, Geological Survey Professional Papers, 525, 79-84.

Oliveira, E.P., Mello, E.F., McNaughton, N., 2002. Reconnaissance U-Pb geochronology of early Precambrian quartzites from Caldeirão belt and their basement, NE São Francisco Craton, Bahia, Brazil: implications for early evolution of the Palaeoproterozoic Salvador-Curaçá Orogen. J. S. Am. Earth Sci. 15 (3), 284-298.

Oliveira, E.P., Windley, B.F., McNaughton, N.J., Pimentel, M., Fletcher, I.R., 2004. Contrasting copper and chromium metallogenic evolution of terranes in the Palaeoproterozoic Itabuna-Salvador-Curaçá orogen, São Francisco craton, Brazil: new zircon (SHRIMP) and Sm-Nd (model) ages and their significance for orogen-parallel escape tectonics. Precambrian Res. 128 (1-2), 143-165.

Paces, J.B., Miller, J.D., 1993. Precise U-Pb ages of Duluth Complex and related mafic intrusions, northeastern Minnesota: geochonological insights to physical, petrogenetic, paleomagnetic and tectonomagmatic processes associated with the 1.1 Ga Midcontinent Rift System. J. Geophys. Res. 98, 13997-14013.

Padilha, A.V., Melo, R.C., 1991. Evolução Geológica da Folha de Pintadas. Texto Explicativo. In: DNPM/CPRM, Programa de Levantamentos Geológicos Básicos do Brasil. Salvador, 129-157.

Pearce, J.A., Harris, N.B.W., Tindle, A.G., 1984. Trace element discrimination diagrams for the tectonic interpretation of granitic rocks. J. Petrol. 25, 956-983.

Peucat, J.J., Mascarenhas, J.F., Barbosa, J.S.F., Souza, S.L., Marinho, M.M., Fanning, C.M., Leite, C.M.M., 2002. 3.3 Ga SHRIMP U-Pb zircon age of a felsic metavolcanic rock from the Mundo Novo Greenstone Belt in the São Francisco Craton, Bahia (NE, Brazil). J. S. Am. Earth Sci. 15, 363-373.

Peucat, J.J., Ménot, R.P., Monnier, O., Fanning, M.C., 1999. The Terre Adélie basement in the East-Antarctica shield: geological and isotopic evidence for a major $1.7 \mathrm{Ga}$ thermal event; comparison with the Gawler Craton in South Australia. Precambrian Res. 94, 205-224.

Peucat, J.J. Santos-Pinto, M., Martin, H. Barbosa, J.S.F., Fanning, M.C., 2003. SHRIMP $\mathrm{U}-\mathrm{Pb}$ zircon ages up to 3.4-3.5 Ga in Archaean and Paleaoproterozoic granitoids of the Gavião Block, São Francisco Craton, Bahia, Brazil. Short papers, IV South American Symposium on Isotope Geology, 252-255.

Pinho, I., Barbosa J., Martin, H., Peucat, J.J., Fanning, C.M., submitted for publication. Geochemical modelling and geochronology of the tonalitic and trondhjemitic granulites from the Itabuna-Salvador-Curaçá Block, Bahia, Brazil.

Plá Cid, J., Rios, D.C., Conceição, H., 2006. Petrogenesis of mica-amphibole-bearing lamprophyres associated with the Paleoproterozoic Morro do Afonso syenite intrusion, eastern Brazil. J. S. Am. Earth Sci. 22 (1-2), 98-115.

Pupin, J.P., 1980. Zircon and granite petrology. Contrib. Mineral. Petr. 73, 207-220.

Rapp, R.P., Watson, E.B., 1995. Dehydratation melting of metabasalt at 8-32 Kbar: implications for continental growth and crust-mantle recycling. J. Petrol. 36 (4), 891-931.

Rickwood, P.C., 1989. Boundary lines within petrologic diagrams which use oxides of major and minor elements. Lithos 22, 247-263.

Rios, D.C., 2002. Granitogênese no Núcleo Serrinha, Bahia, Brasil: Geocronologia e Litogeoquimica. PhD Thesis. Universidade Federal da Bahia, Brazil, 233 pp.

Rios, D.C., Conceicão, H., Davis, D.W., Pl'a Cid, J., Rosa, M.L.S., Macambira, M.J.B., McReath, I., Marinh, M.M., Davis, W.J., 2007. Paleoproterozoic potassic-ultrapotassic magmatism: Morro do Afonso syenite pluton, Bahia, Brazil. Precambrian Res. 154, 1-30.
Rosa, M. de L. da S., 1994. Magmatismo shoshonítico e ultrapotássico no sul do Cinturão Móvel Salvador-Curaçá, Maciço de São Felix, geologia, mineralogia e geoquímica. Dissertação de Mestrado. UFBA, 240 pp.

Rosa, M. de L. da S., 1998. Magmatismo shoshonítico e ultrapotássico no sul do Cinturão Móvel Salvador-Curaçá, Maciço de São Felix: geologia, mineralogia e geoquímica. In: Sienitos alcalino-potássicos e ultrapotássicos Paleoproterozoicos do Estado da Bahia. In: Conceição, H, Cruz, M.J.M. (Eds.), Publicação Especial $n^{\circ} 4$, Soc. Bras. Geoc., Nucleo Bahia-Sergipe, 4-37.

Rosa, M. de L. da S., Conceição, H., Macambira, M.J.B., Scheller, T., Martin, H. Bastos Leal, L.R., 2001. Idades $\mathrm{Pb}-\mathrm{Pb}$ e assinatura isotópica $\mathrm{Rb}-\mathrm{Sr}$ e $\mathrm{Sm}$ Nd do magmatismo sienítico paleoproterozóico no sul do Cinturão Móvel Salvador-Curaçá: Maciço Sienítico de São Felix, Bahia. Rev. Bras. Geoci. 31 (3), 390-400.

Santos Pinto, M.A., 1996. Le recyclage de la croûte continentale archéene: Exemple du bloc du Gavião-Bahia, Brésil. PhD Thesis. Universidade de Rennes I, 193 pp.

Santos Pinto, M.A., Peucat, J.J., Martin, H., Sabaté, P., 1998. Recycling of the Archaean continental crust: the case study of the Gavião, State of Bahia, NE, Brazil. J. S. Am Earth Sci. 11 (5), 487-498.

Shand, S.J., 1950. Eruptive rocks, 4th ed. Murby, London.

Silva, M.G. da, 1996. Sequências Metassedimentares, Vulcanossedimentares e Greenstone Belts do Arqueano e Proterozoico Inferior. In: Barbosa, J.S.F., Dominguez J.M.L. (Eds.), Geologia da Bahia: Texto Explicativo para o Mapa Geológico ao Milionésimo. SICM/SGM, Salvador, pp. 85-102.

Silva, L.C., Armstrong, R., Delgado, I.M., Pimentel, M.M., Arcanjo, J.B., Melo, R.C.de. Teixeira, L.R., Jost, H., Cardoso Filho, J.M., Pereira, L.H.M., 2002. Reavaliação da evolução geológica em terrenos pré-cambrianos brasileiros com base em novos dados U-Pb SHRIMP. Parte I. Limite centro-oriental do Cráton do São Francisco na Bahia. Rev. Bras. Geoci. 32 (4), 501-512.

Silva, L.C., McNaughton, N.J., Melo, R.C., Fletcher, I.R., 1997. U-Pb SHRIMP ages in the Itabuna-Caraíba TTG high-grade complex: the first window beyond the Paleoproterozoic overprinting of the eastern Jequié craton, NE Brazil. In: International Symposium on Granites and Associated Mineralizations, 2, Salvador. Proceedings, Sociedade Brasileira de Geologia, 282-283.

Stacey, J.S., Kramers, J.D., 1975. Approximation of terrestrial lead isotopic evolution by a two stage model. Earth Planet. Sci. Lett. 26, 207-221.

Steiger, R.H., Jäger, E., 1977. Subcommission on geochronology: convention to use of constants in geo and cosmology. Earth Planet. Sci. Lett. 36, 359-362.

Streckeisen, A., 1975. How should charnockitic rocks be named? Geologie des Domaines Cristalines. Liege. Centenaire Soc. Geolog. de Belgique, 1, 349-360.

Sun, S.S., 1982. Chemical composition and origin of the Earth's primitive mantle Geochim. Cosmochim. Acta 46, 169-192.

Teixeira, L.R., 1997. O Complexo Caraíba e a Suite São José do Jacuipe no Cinturão Salvador-Curaçá (Bahia-Brasil): Petrologia, Geoquímica e Potencial Metalogenético. PhD Thesis. Universidade Federal da Bahia, 201 pp.

Watson, E.B., Harrison, M.T., 1983.Zircon saturation revisited: temperature and composition effects in a variety of crustal magma types. Earth Planet. Sci. Lett. 64, 295-304.

Wilson, N., 1987. Combined $\mathrm{Sm}-\mathrm{Nd}, \mathrm{Pb} / \mathrm{Pb}$ and $\mathrm{Rb} / \mathrm{Sr}$ geochronology and isotope geochemistry in polymetamorphic Precambrian terrains: examples from Brazil and Channel Island. U.K. Master of Science. Oxford University, U.K. $101 \mathrm{pp}$.

Winge, M., 1984. A Seqüência Vulcanossedimentar do Grupo Rio Capim, Bahia. In: Viveiro Sá, P.V. da S., Duarte, F.B. (Eds.), Geologia e Recursos Minerais do Estado da Bahia, Salvador, vol. 5. SME/CPM, Brazil, pp. 43-103, Special Publication. 